\title{
Influence of Flagellin Polymorphisms, Gene Regulation, and Responsive Memory on the Motility of Xanthomonas Species That Cause Bacterial Spot Disease of Solanaceous Plants
}

\author{
Maria L. Malvino, Amie J. Bott, Cory E. Green, Tanvi Majumdar, and Sarah R. Hind ${ }^{\dagger}$ \\ Department of Crop Sciences, University of Illinois, Urbana, IL 61801, U.S.A.
}

Accepted 25 October 2021.

\begin{abstract}
Increasingly, new evidence has demonstrated variability in the epitope regions of bacterial flagellin, including in regions harboring the microbe-associated molecular patterns flg22 and flgII-28 that are recognized by the pattern recognition receptors FLS2 and FLS3, respectively. Additionally, because bacterial motility is known to contribute to pathogen virulence and chemotaxis, reductions in or loss of motility can significantly reduce bacterial fitness. In this study, we determined that variations in flg22 and flgII-28 epitopes allow some but not all Xanthomonas spp. to evade both FLS2- and FLS3-mediated oxidative burst responses. We observed variation in the motility for many isolates, regardless of their flagellin sequence. Instead, we determined that past growth conditions may have a significant impact on the motility status of isolates, because we could minimize this variability by inducing motility using chemoattractant assays. Additionally, motility could be significantly suppressed under nutrient-limited conditions, and bacteria could "remember" its prior motility status after storage at ultracold temperatures. Finally, we observed larger bacterial populations of strains with flagellin variants predicted not to be recognized by either FLS2 or FLS3, suggesting that these bacteria can evade flagellin recognition in tomato plants. Although some flagellin variants may impart altered motility and differential recognition by the host immune system, external growth parameters and gene expression regulation appear to have more significant impacts on the motility phenotypes for these Xanthomonas spp.
\end{abstract}

Keywords: bacterial pathogenesis, bacterial spot, elicitors, flagellin, MAMPs, motility, tomato, Xanthomonas

${ }^{\dagger}$ Corresponding author: S. R. Hind; srhind@illinois.edu

Funding: This study was supported, in part, by funding from the United States Department of Agriculture National Institute of Food and Agriculture Hatch ILLU-802-945 (to S. R. Hind) and a University of Illinois at Urbana-Champaign College of Agricultural, Consumer and Environmental Sciences Undergraduate Research Scholarship (to T. Majumdar).

*The $\boldsymbol{e}$-Xtra logo stands for "electronic extra" and indicates that supplementary materials are published online.

The author(s) declare no conflict of interest.

(c) (1) Copyright $\odot 2022$ The Author(s). This is an open access article distributed under the CC BY 4.0 International license.
Motility is an ancient characteristic of prokaryotes and is closely related to chemotaxis, which is the capacity of the bacteria to orientate along a chemical gradient. These features are essential for bacteria to adapt to changing environmental conditions (Ottemann and Miller 1997). Bacteria move toward favorable environments to acquire nutrients and identify suitable places to colonize, behaviors that are possible due to these motility and chemoattractant capacities. Many bacteria use taillike structures called flagella to move within their environment. There are additional types of bacterial movements that do not involve flagella such as twitching, actin-based intracellular motility, and gliding motility; however, flagellum-dependent motility that includes swimming and swarming is the best characterized type of motility (Josenhans and Suerbaum 2002).

The flagellum is a rotating organelle that includes a type III secretion system, which includes a molecular motor in the inner bacterial membrane, a hook-basal body complex that acts as a junction element, and a rotating filament that is composed of several thousand flagellin protein subunits (Josenhans and Suerbaum 2002). Flagellated bacteria expend a large amount of energy to produce the flagellum and to power flagellum-dependent movement (Josenhans and Suerbaum 2002; Ottemann and Miller 1997). Thus, expression and synthesis of flagellum components are tightly regulated. Flagellin is encoded by the gene $\mathrm{fliC}$, which is usually found as part of the conserved flagellum gene cluster (Ausubel 2005). Flagellin proteins have conserved N-terminal and C-terminal domains that are located within the center of the flagellum structure, whereas regions that are more surface exposed have increased variability between different bacterial species (Fliegmann and Felix 2016).

Plants have evolved multiple cell surface pattern-recognition receptors (PRRs) that can recognize either buried or surfaceexposed regions of flagellin. Initially identified in Arabidopsis thaliana, FLAGELLIN SENSING 2 (FLS2) is a PRR that is present broadly across the plant kingdom and recognizes the flagellin-derived 22-amino-acid peptide called flg22, considered a microbe-associated molecular pattern (MAMP) (Saijo et al. 2018; Zipfel et al. 2004). In addition to FLS2, other PRRs can recognize regions of flagellin. The solanaceous-specific FLAGELLIN SENSING 3 (FLS3) receptor recognizes the 28-aminoacid peptide called flgII-28, another MAMP (Cai et al. 2011; Hind et al. 2016). Although tomato (Solanum lycopersicum) plants have both FLS2 and FLS3 receptors, subtle differences between these PRRs indicate that they may have nonredundant functionality (Roberts et al. 2020). In potato (S. tuberosum), flgII-28 treatment induces greater defense responses compared with flg22 (Moroz and Tanaka 2020). Rice (Oryza sativa) also 
possess a second flagellin receptor that recognizes a region separate from flg22 (Che et al. 2000; Takai et al. 2008); however, neither the PRR nor the specific MAMP have been identified.

Chemotactic movements are important for plant pathogens, particularly at early stages of infection (Chatterjee et al. 2010; Kamoun and Kado 1990; Moreira et al. 2015; Shen and Ronald 2002; Yaryura et al. 2015). For most phytopathogens, chemotaxis and motility are necessary to find and enter the host plant through natural openings such as stomata, hydathodes, wounds, and roots (Huang 1986), although motility or chemotaxis are not necessary for pathogen virulence if the pathogen is directly inoculated into the host plant (An et al. 2014; Yaryura et al. 2015). Additionally, the flagella can help adhere the pathogenic bacteria to its host (Merritt et al. 2007; Yu et al. 2013). Bacteria are known to switch from motile to nonmotile states after successful host infection, and this phenotypic plasticity occurs, in part, through changes in expression of the flagellum-related genes, including $\mathrm{fliC}$ (Vinatzer et al. 2014). The foliar pathogen Pseudomonas syringae pv. syringae decreases expression of flagellar and chemotaxis genes when switching from epiphytic to apoplastic growth (Yu et al. 2013). After the vascular pathogen Ralstonia solanacearum enters the xylem, the bacteria reduce their expression of $f i C$, leading to decreased motility (Tans-Kersten et al. 2004). Additionally, Xanthomonas oryzae pv. oryzae requires $\mathrm{fliC}$ expression to enter stomata in rice leaves (Kumar Verma et al. 2018). Although many phytopathogenic bacteria with reduced or absent flagella have concomitant reductions in virulence, some nonflagellated or nonmotile bacteria are also virulent on plants (Matilla and Krell 2018).

Bacteria in the genus Xanthomonas are Gram negative and rod shaped, and most species have a single polar flagellum. Members of this large group of phytopathogens can infect almost 400 plant species, although individual species or pathovars usually have narrow host ranges (Potnis et al. 2015). There are four species of Xanthomonas that cause bacterial spot disease in members of the Solanaceae family, which includes tomato, pepper, and chili pepper plants. These species include $X$. euvesicatoria, $X$. vesicatoria, $X$. perforans, and $X$. gardneri. Bacterial spot symptoms include small necrotic lesions that can occur on all aboveground plant parts. The disease is globally rampant, in part because it is seedborne, but also because these bacteria can infect solanaceous host plants at a wide range of temperatures (Jones et al. 1986).

Better understanding of host-pathogen interactions increases the chances of developing disease-resistant crops. Diseaseresistant plants are especially important for crops affected by devastating bacterial diseases such as bacterial spot disease incited by Xanthomonas spp., which cause significant annual yield losses. We hypothesized that flagellin polymorphisms may help Xanthomonas spp. avoid host recognition but that some of these polymorphisms could reduce bacterial motility. In this study, flagellin proteins were characterized for the four Xanthomonas spp. pathogenic on tomato and pepper plants. Six flagellin variants were identified, and a collection of isolates was evaluated for variations in motility as well as for motility shifts under inductive and suppressive conditions. In addition, isogenic strains expressing the flagellin variants were created and evaluated for differences in motility as well as exposed to different environmental conditions in order to evaluate changes in $\mathrm{flC}$ expression. Finally, tomato plants were inoculated with the isogenic strains to test for altered virulence caused by differential flagellin recognition.

\section{RESULTS}

Xanthomonas flg22 and flgII-28 polymorphisms affect oxidative burst responses in tomato.

Given the importance of bacterial spot disease on worldwide tomato and pepper production, we wanted to know whether variability in the flgII-28 region of flagellin found in different Xanthomonas spp. impacts recognition by host plants. We first sought to test the findings from previous studies that indicated that Xanthomonas flagellin was not recognized by tomato plants (Felix et al. 1999). We identified two different flg22 epitopes present in the four Xanthomonas spp. that infect tomato and pepper plants. One variant is present in $X$. euvesicatoria and $X$. perforans, while the other variant is found in $X$. gardneri; these peptides differ by four amino acid residues and differ from the canonical flg22 sequence from $P$. aeruginosa by nine and eight residues, respectively (Fig. 1A). Notably, the Xanthomonas flg22 epitopes have a valine at position 43 instead of the conserved aspartic acid. This residue is important for full activity of the peptide (Felix et al. 1999) and for binding to the FLS2 receptor (Meindl et al. 2000; Parys et al. 2021; Sun et al. 2013), and the D43V variant leads to loss of flg22 perception in $A$. thaliana (Naito et al. 2008; Sun et al. 2006; Wang et al. 2015), Nicotiana tabacum (Naito et al. 2008), and O. sativa (Wang et al. 2015). Polymorphisms in the D43 residue can also reduce bacterial motility (Naito et al. 2008; Parys et al. 2021). An additional variant was identified from $X$. vesicatoria that differed by only one residue (position 42) from the $X$. euvesicatoria/X. perforans variant; however, because this residue matched the amino acid found in the X. gardneri variant (Supplementary Table S1), we decided not to include it in our experiments. Neither flg22 peptide from Xanthomonas spp. was recognized by tomato leaves, as measured by oxidative burst assays, whereas the canonical flg22 elicited a strong response (Fig. 1C and D).

Next, we identified several flgII-28 variants from Xanthomonas spp., including one that is present in some X. campestris pv. campestris species, another that is found in strains of many Xanthomonas spp., and a third that is uniquely present in $X$. euvesicatoria strains (Fig. 1B). The $X$. euvesicatoria variant differs from the Xanthomonas consensus variant by one amino acid residue, and both differ from the $X$. campestris variant by six or five residues, respectively. Compared with the robust activity elicited by the flgII-28 from $P$. syringae pv. tomato T1, the oxidative burst response of the $X$. campestris and Xanthomonas consensus variants was significantly reduced but still greater than the water control (Fig. 1C and D). However, there was no difference in the response between the water control and X. euvesicatoria flgII-28 treatments, indicating that this flgII-28 variant cannot be recognized by tomato FLS3. Together, these results suggest that some but not all Xanthomonas spp. can evade both FLS2- and FLS3-mediated oxidative burst responses in tomato.

\section{Flagellin polymorphisms in Xanthomonas pathogenic strains that cause bacterial spot disease.}

Given the importance of motility for Xanthomonas to naturally infect their host plants (An et al. 2014; Yaryura et al. 2015), we wanted to know whether the variations present in flagellin sequences from different Xanthomonas spp. affected the motility of the bacteria. First, we performed an in silico analysis of flagellin using sequence information deposited in the NCBI. We identified six flagellin protein variants in the four Xanthomonas spp. that cause disease in solanaceous species. One variant was found in $X$. euvesicatoria strains (flgXe-1), two variants were identified from $X$. perforans strains (flgXp-1 and flgXp-2), one variant was found in $X$. vesicatoria strains (flgXv-1), and two variants were identified from $X$. gardneri strains (flgXg-1 and flgXg-2) (Supplementary Table S1). The identity between the variants matched the phylogenetic relationships between the species (Jacques et al. 2016), with the greatest similarity between $X$. euvesicatoria and $X$. perforans variants, followed by less similarity between these three variants and the variant found in $X$. vesicatoria, and finally the greatest sequence divergence with the $X$. gardneri strains (Fig. 2). 
A

flagellin

residue \# $30 \quad 31 \quad 32 \quad 33 \quad 3435 \quad 36 \quad 37 \quad 38 \quad 3940 \quad 41 \quad 42 \quad 43 \quad 44 \quad 45 \quad 46 \quad 47 \quad 4849 \quad 50 \quad 51$

$\begin{array}{llllllllllllllllllllllll}\text { flg22 } & Q & R & L & S & T & G & S & R & I & N & S & A & K & D & D & A & A & G & L & Q & I & A\end{array}$

$\begin{array}{lllllllllllllllllllllll}\text { flg22 } & X e & Q & Q & L & S & S & G & K & R & I & T & S & F & A & V & D & A & A & G & G & A & I\end{array}$

\begin{tabular}{llllllllllllllllllllllll} 
flg22 Xg & $Q$ & $Q$ & $L$ & $S$ & $S$ & $G$ & $K$ & $R$ & $I$ & $T$ & $S$ & $A$ & $S$ & $V$ & $D$ & $A$ & $A$ & $G$ & $L$ & $A$ & $I$ & $S$ \\
\hline
\end{tabular}

$\begin{array}{llllllllllllllllllllllllll}\text { peptide } & 1 & 2 & 3 & 4 & 5 & 6 & 7 & 8 & 9 & 10 & 11 & 12 & 13 & 14 & 15 & 16 & 17 & 18 & 19 & 20 & 21 & 22\end{array}$

residue \#

B

flagellin

residue \# 84858687888990919293949596979899100101102103104105106107108109110111

$\begin{array}{lllllllllllllllllllllllllllll}\text { flgII-28 } & \text { E } & S & T & N & I & L & Q & R & M & R & E & L & A & V & Q & S & R & N & D & S & N & S & S & T & D & R & D & A\end{array}$

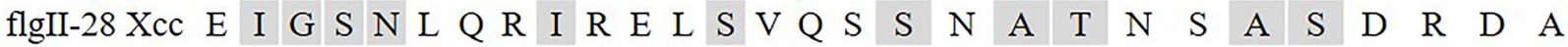
$\begin{array}{lllllllllllllllllllllllllllll}\text { flgII-28 Xan } & E & \text { I } & G & N & N & L & Q & R & I & R & E & L & S & V & Q & S & A & N & A & T & N & S & S & T & D & R & E & A\end{array}$ \begin{tabular}{cccccccccccccccccccccccccccccccc} 
flgII-28 Xe & E & I & G & $N$ & $N$ & L & Q & R & I & R & E & L & S & V Q & S & A & K & A & T & N & S & S & T & D & R & E & A \\
\hline peptide & 1 & 2 & 3 & 4 & 5 & 6 & 7 & 8 & 9 & 10 & 11 & 12 & 13 & 14 & 15 & 16 & 17 & 18 & 19 & 20 & 21 & 22 & 23 & 24 & 25 & 26 & 27 & 28
\end{tabular} residue \#
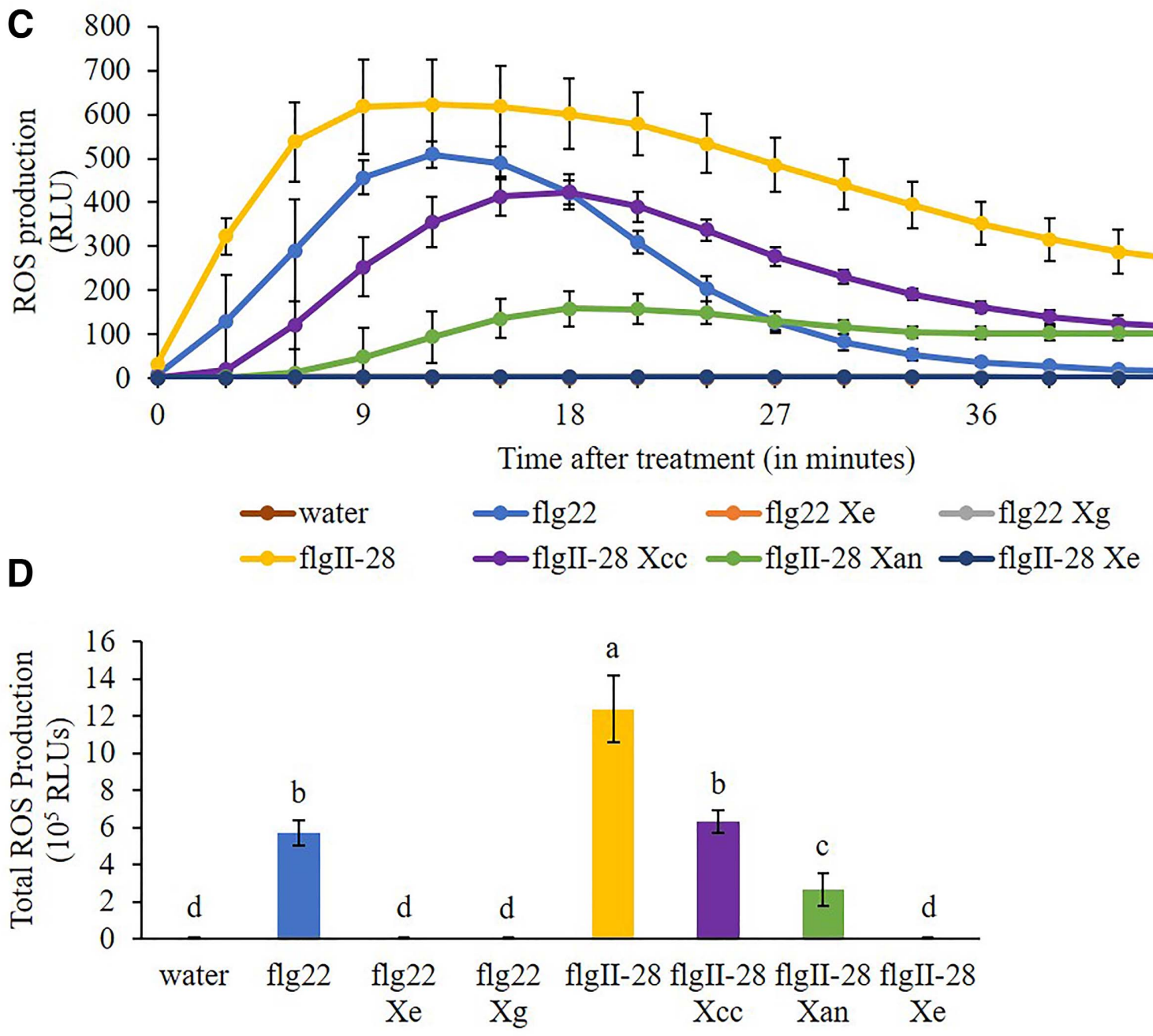

Fig. 1. Polymorphisms in conserved flagellin regions prevent immune recognition by tomato plants. Comparisons of $\mathbf{A}$, flg22 and $\mathbf{B}$, flgII-28 sequences. Reference sequences are flg22 from Pseudomonas aeruginosa (Felix et al. 1999) and flgII-28 from P. syringae pv. tomato T1 (Cai et al. 2011). The top line indicates the residue position using the Xanthomonas flagellin sequence, the bottom line indicates the residue position within the peptide sequence, and shaded resides indicate polymorphisms relative to the references. C and D, Oxidative burst produced by Solanum lycopersicum 'Brandywine' tomato plants. Leaf disks were treated with $100 \mathrm{nM}$ peptide or water, and the total amount of reactive oxygen species (ROS) was measured over 45 min and quantified using relative light units (RLUs). Results shown are the means of three independent experiments, with error bars indicating the standard error of the means ( $n=4$ plants per experiment, with each plant consisting of three disks per treatment). Different letters indicate significant differences between treatments $(P<0.05$, one-way analysis of variance using least squares method). 
Next, we tested the motility of a collection of Xanthomonas isolates. The collection included $18 X$. euvesicatoria isolates, $8 X$. perforans isolates, $4 X$. vesicatoria isolates, and $5 X$. gardneri isolates (Supplementary Table S2). The $f i C$ gene was sequenced for all strains and the results confirmed that we had isolates with all of the six possible flagellin variants. We performed motility assays for each of the strains and, although we observed that motility differed greatly between the strains, there was no clear pattern of differences based on the flagellin variant that each strain possessed (Fig. 3).

It has been shown previously that $X$. oryzae pv. oryzae bacteria grown on solid $(>1 \%)$ agar media are not flagellated (Shen et al. 2001). However, Xanthomonas spp. can switch from nonmotile to motile states, with the increased motility related to chemotactic behavior (Kamoun and Kado 1990; Shen et al. 2001). We hypothesized that growth on solid media may have unequally altered the motility for the strains in our collection and, therefore, we decided to test whether bacterial motility could be induced using chemotactic attraction assays. Because methionine has been shown to induce motility for Xanthomonas spp. (Kumar Verma et al. 2018), we initially evaluated the chemoattraction potential for all isolates using methionine and observed that 17 of the 35 isolates showed increased motility after treatment (Supplementary Tables S2 and S3). To select additional compounds to test for chemoattraction, we used KBase (Arkin et al. 2018) to predict potential auxotrophies using a reference genome for each Xanthomonas sp. We performed chemoattraction assays using nine additional compounds, with varying success (Supplementary Table S3). Some of the isolates that did not respond to any of the treatments were already fairly motile (e.g., X0008 and X0010); thus, it was likely that they could not further increase their motility. Other isolates, including the reference $X$. euvesicatoria 85-10 strain (X0001), did increase their motility in response to treatment with other compounds (Supplementary Tables S2 and S3; Supplementary Fig. S3C and D), although there was not a pattern in this response. Interestingly, the $X$. gardneri isolates did not increase their motility in response to any of the chemoattractant compounds tested (Supplementary Table S3), with all isolates showing less motility when compared with isolates of the other three species (Figs. 3 and 4).

Once we were able to induce bacterial motility, we wanted to test whether we could shift the isolates from motile to nonmotile states using growth on minimal media (MM) (Kamoun and Kado 1990). We observed reduced motility of all Xanthomonas isolates except one (X0034) after 4 days of growth on MM (Fig. 3; Supplementary Table S2). When the motilities of isolates with identical flagellin variants were grouped together, each of the four groups showed significantly reduced motility after growth on MM (Fig. 4), indicating that motility phenotypes can be altered depending on the growth media. Because we had only one isolate each for flagellin variants flgXp-2 and flgXg-2, we were unable to determine the average motility for these variants. When we compared the motility of individual strains under inductive versus suppressive conditions, we saw more variability for the strains with the flgXe-1 and flgXp-1 variants as compared with those with the flgXv-1 and flgXg-1 variants (Supplementary Fig. S4). This is likely due to an overall lower number of strains with the flgXv-1 and flgXg-1 variants as well as the lower induced motility of these strains.

To test whether prior motility induction conditions affect the motility phenotype of the isolates, we assessed motility of the isolates before and after storage at ultracold temperatures. We hypothesized that, because these isolates came from different sources, they could have undergone different handling over time and thus have "remembered" these different conditions, despite our uniform handling and preservation methods. The ability of bacteria to "remember" past events to influence current behavior is a phenomenon termed "response memory" and has been documented in other bacteria, including altered virulence phenotypes in P. aeruginosa (Kordes et al. 2019), changes in stimuliinduced chemotactic behaviors in Escherichia coli (Gosztolai and Barahona 2020), and persistence of gene expression after removal of the carbon inducer in E. coli (Lambert and Kussell 2014). In order to test this, motility was induced and isolates
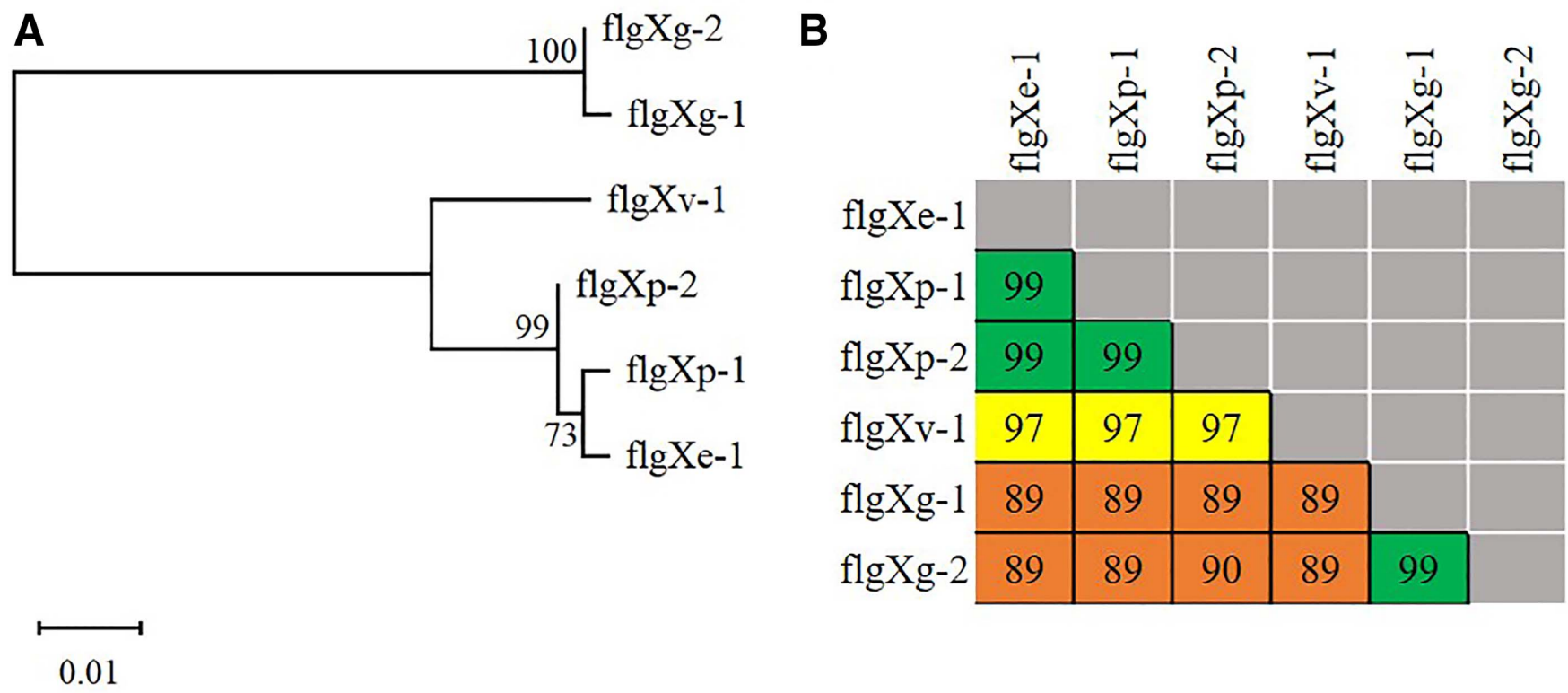

Fig. 2. Phylogenetic relationship and sequence similarity of flagellin variants from four Xanthomonas spp. A, Phylogenetic analysis of six flagellin protein variants from Xanthomonas spp. that are pathogenic for tomato and pepper. Variants include flagellin sequences from Xanthomonas euvesicatoria (flgXe-1), X. perforans (flgXp-1 and flgXp-2), X. vesicatoria (flgXv-1), and X. gardneri (flgXg-1 and flgXg-2). Branch lengths are measured in the number of substitutions per site from a total of 399 positions, and the branches are annotated with a number representing the percentage of trees in which the associated taxa clustered together. B, Identity matrix showing the percent similarity between the amino acid sequences of the flagellin variants. Green shading indicates high similarity, yellow shading indicates moderately high similarity, and orange shading indicates moderate similarity. 


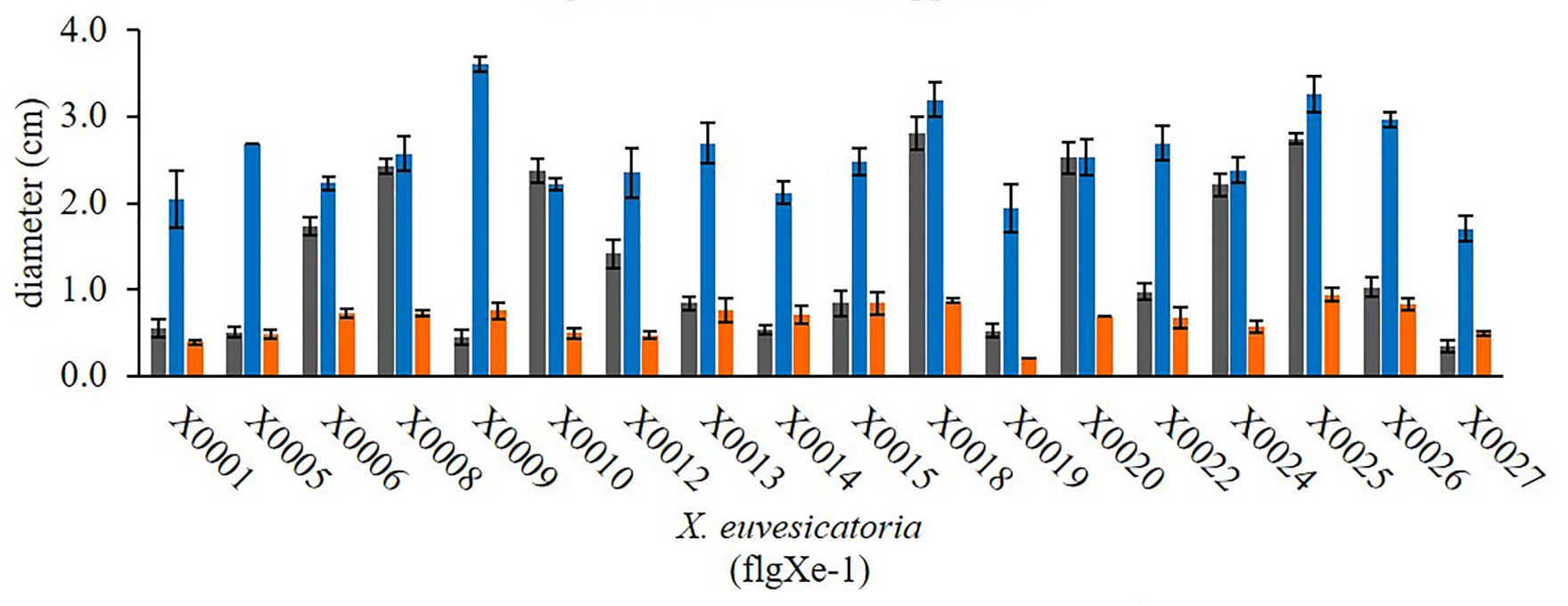

B
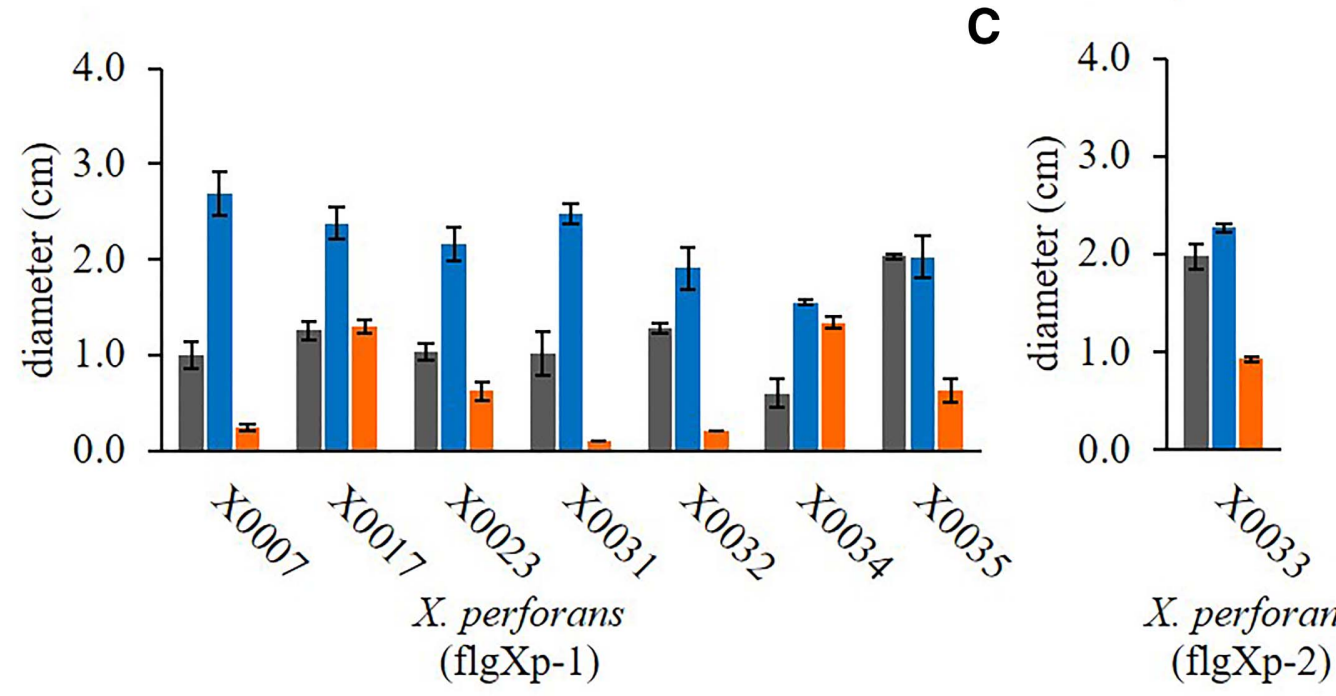

(flgXp-1)

X. perforans

(flgXp-2)
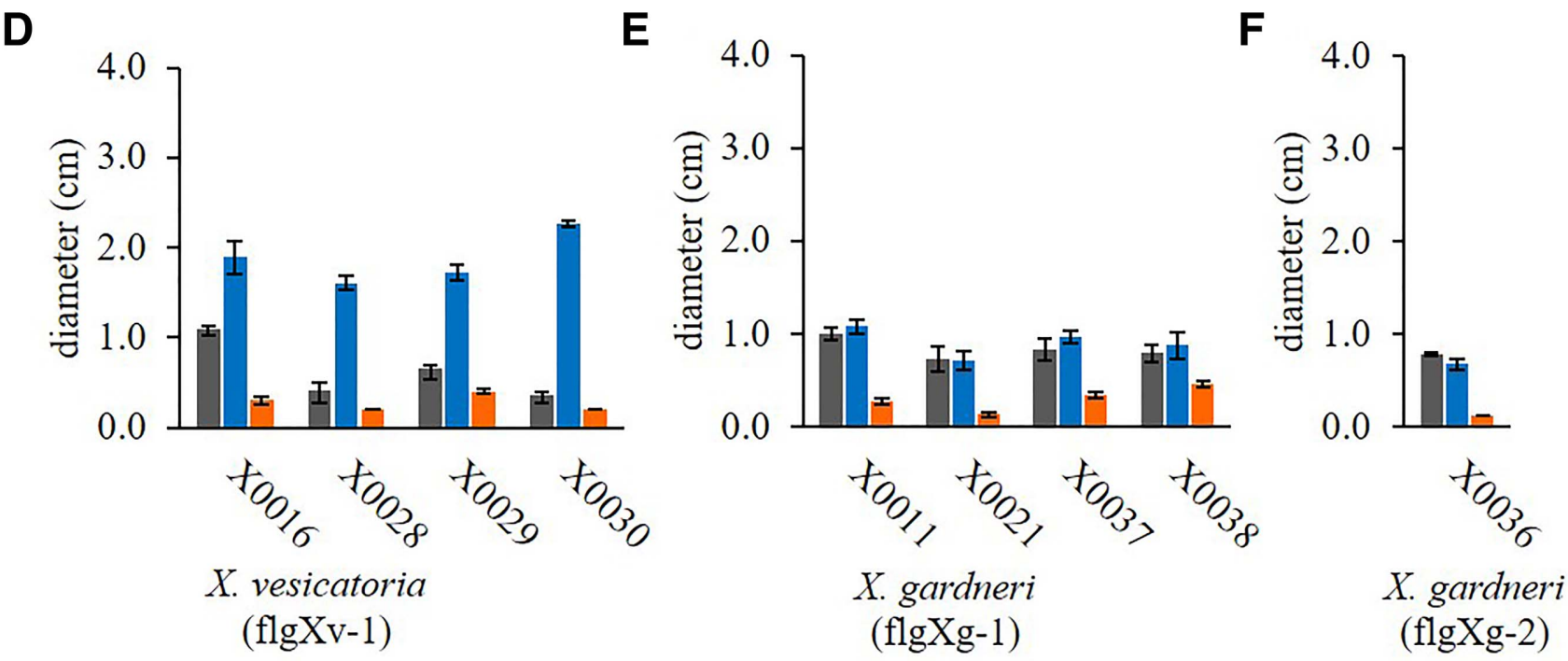

Fig. 3. Comparison of motility of Xanthomonas isolates under inductive and suppressive conditions. For each isolate, motility was assessed prior to any intervention (original), after growth on nutrient media containing chemoattractant chemicals (induced), or after growth on minimal nutrient media (suppressed). Motility was quantified at $24 \mathrm{~h}$ (for suppressed) or $48 \mathrm{~h}$ (for original and induced) after inoculation by measuring the diameter of the circular halo formed in the media by the swimming bacteria. Data shown are means of three independent experiments, with error bars indicating the standard error of the means $(n=$ 4 replicates per experiment). Motility of $\mathbf{A}, 18$ Xanthomonas euvesicatoria isolates with the flgXe-1 variant; $\mathbf{B}$, 7 X. perforans isolates with the flgXp- 1 variant; C, 1 X. perforans isolate with the flgXp-2 variant; D, 4 X. vesicatoria isolates with the flgXv-1 variant; E, 4 X. gardneri isolates with the flgXg-1 variant; and F, 1 X. gardneri isolate with the flgXg-2 variant. Specific chemoattractants used for each isolate can be found in Supplementary Table S2. 
were either immediately evaluated using motility assays, or suspended in $20 \%$ glycerol and stored at $-80^{\circ} \mathrm{C}$. Isolates stored at ultracold conditions were streaked onto solid agar media (peptone sucrose media [PSA] with $1.2 \%$ agar); then, motility was evaluated. No differences were observed between the motility of the strains before and after ultracold storage (Fig. 5), suggesting that growth conditions prior to storage influenced the motility phenotypes of bacteria. We attempted similar experiments for motility suppression using growth on MM; however, we observed that poststorage growth of isolates on solid agar nutrient media was sufficient to induce some motility of the strains (data not shown). Together, these results suggest that it is possible to switch the motility phenotypes of Xanthomonas isolates using artificial bacteriological media to induce motility, and that the variability in motility that we originally observed was likely due to past growth conditions.

\section{Motility and $f l i C$ expression}

\section{of $X$. euvesicatoria isogenic strains.}

In order to directly compare the motility potential of the different flagellin variants, we constructed isogenic strains that varied only in their $\mathrm{fliC}$ genes. Using biparental mating and double recombination of the pK18mobsacB suicide plasmid, we generated a $\mathrm{fliC}$ deletion mutant in the reference strain $X$. euvesicatoria $85-10(85-10 \Delta f i C)$ by biparental mating. The

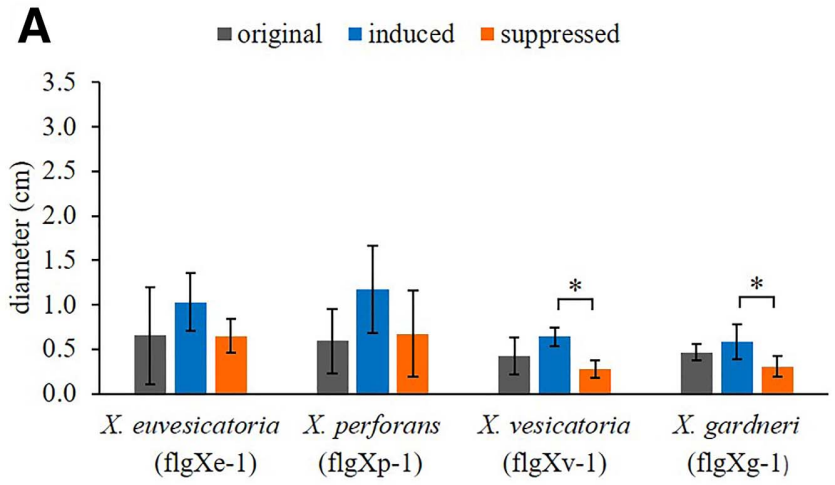

B

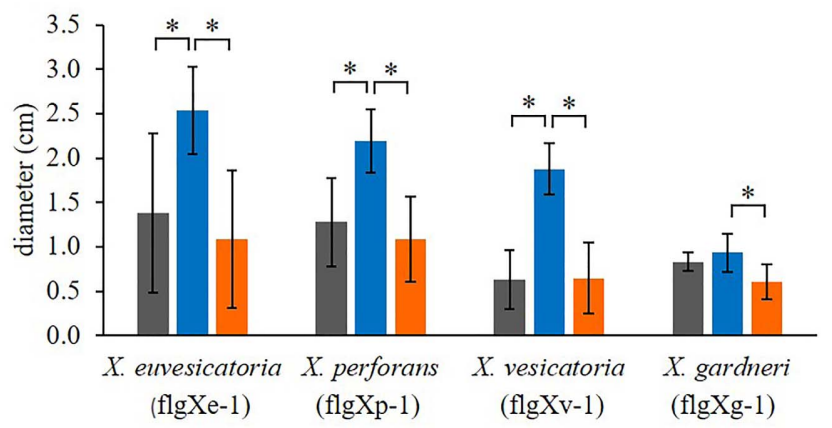

Fig. 4. Comparison of motility for each Xanthomonas sp. under inductive and suppressive conditions. For each species, the average motility for each isolate was assessed prior to any intervention (original), after growth on nutrient media containing chemoattractant chemicals (induced), or after growth on minimal nutrient media (suppressed). Motility was quantified at $\mathbf{A}, 24 \mathrm{~h}$ and $\mathbf{B}, 48 \mathrm{~h}$ after inoculation by measuring the diameter of the circular halo formed in the media by the swimming bacteria. Data shown are the mean motility of isolates for each species, with error bars indicating the standard deviation ( $n=18$ isolates for flgXe-1, 7 isolates for $\mathrm{flgXp}-1,4$ isolates for flgXv-1, and 4 isolates for flgXg-1). Asterisks indicate significant differences between inductive and suppressive treatments for each species $(P<0.05$, one-way analysis of variance using Kruskal-Wallis test followed by Dunn's posthoc test). Specific chemoattractants used for each isolate can be found in Supplementary Table S2.
$\mathrm{fliC}$ gene was replaced in-frame with the tetracycline resistance gene, and replacement was confirmed using PCR (Supplementary Fig. S2B). As expected, the 85-10 $\Delta$ fliC strain was nonmotile (Supplementary Fig. S2). Next, the tetracycline resistance gene was replaced by one of six alleles $\left(f l i C_{X e-1}, f i C_{X p-1}, f i C_{X p-2}\right.$, $f i C_{X v-1}, f i C_{X g-1}$, or $\left.f l i C_{X g-2}\right)$, and gene replacement for all strains was confirmed using PCR (Supplementary Fig. S2D). All isogenic strains had similar induced motility after treatment with the chemoattractant thymidine (Fig. 6A), which was used because $X$. euvesicatoria $85-10$ (X0001) was not responsive to treatment with methionine (Supplementary Table S3). Motility was significantly suppressed in the isogenic strains after growth on MM, although the level of suppression was more variable compared with motility induction (Fig. 6A).

Significant differences in motility induction between isogenic strains were present after $48 \mathrm{~h}$ of growth in soft agar plates (Fig. 6B). Surprisingly, unlike the results observed for the isolate collection, the strains with the $X$. gardneri flagellin variants were more motile than some of the other alleles, with the strain expressing the flgXg-2 variant having motility comparable with that observed for both $X$. perforans variants (flgXp-1 and flgXp-2) (Fig. 6B). These results could be explained by differences in the intrinsic motility activity of each variant or by differences in expression of the different alleles.

We expected that expression of $\mathrm{flC}$ should have been similar in all isogenic strains, given that the promoter and terminator sequences were identical in each strain. Surprisingly, we observed significant differences in expression of the different alleles, with $f i C$ alleles from $X$. perforans having greater expression and those from $X$. vesicatoria have less expression when compared with the $f i C$ allele from $X$. euvesicatoria (Fig. 7A; Supplementary Fig. S5A). These expression results correspond to the greater and lesser motility of the corresponding strains (Fig. 6B). However, although the $f i C$ alleles from $X$. gardneri were significantly less expressed compared with the strain with the $f i C$ allele from $X$. euvesicatoria (Fig. 7A), this difference did not correlate with the observed motility of the strains (Fig. 6B). This discrepancy suggests that factors other than flagellar expression may affecting motility for strains containing

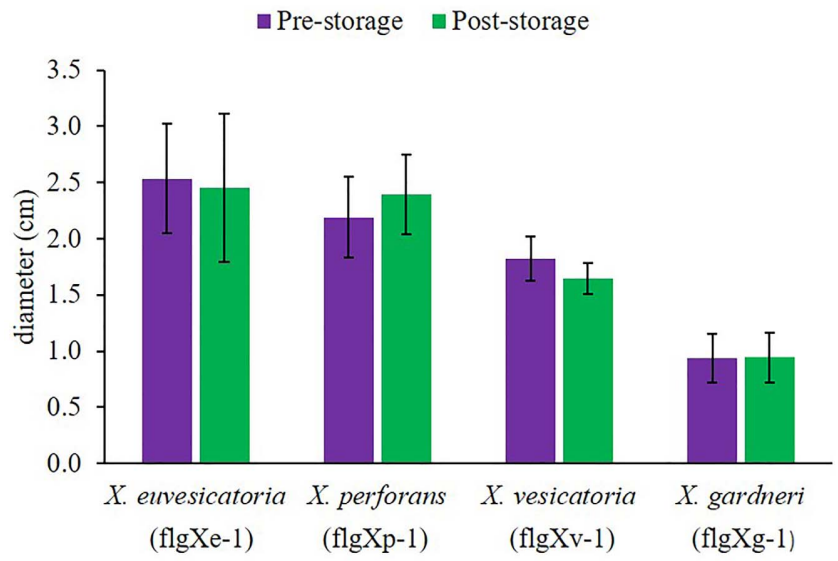

Fig. 5. Evaluation of motility changes after storage at ultralow-temperature conditions. For each species, the average motility for each isolate was assessed after growth on nutrient media containing chemoattractant chemicals. Motility was quantified either before (prestorage) or after (poststorage) bacteria were stored at ultralow-temperature conditions $\left(-80^{\circ} \mathrm{C}\right)$. Data shown are the mean motility of isolates for each species, with error bars indicating the standard deviation ( $n=18$ isolates for flgXe-1, 7 isolates for flgXp-1, 4 isolates for flgXv-1, and 4 isolates for flgXg-1). No significant differences were observed between the treatments for each species $(P<$ 0.05 , one-way analysis of variance using Kruskal-Wallis test followed by Dunn's posthoc test). Specific chemoattractants used for each isolate can be found in Supplementary Table S2. 
the $X$. gardneri variants. As anticipated, the expression of $f i C$ was significantly less in all strains after growth on MM (Fig. 7B; Supplementary Fig. S5B), supporting the corresponding motility changes observed for the strains (Fig. 6A).

\section{Altered virulence phenotypes}

\section{of $X$. euvesicatoria isogenic strains.}

Finally, in order to assess the effects of the flagellin polymorphisms on plant immunity, we performed in planta bacterial virulence assays using vacuum infiltration. Plants of tomato cultivar 'Brandywine' were inoculated with suspensions containing either one of the six isogenic strains, the reference strain $X$. euvesicatoria 85-10, or the $X$. euvesicatoria $\Delta f i C$ mutant strain, and bacterial populations were determined at 0,6 , and 9 days postinoculation (dpi). We observed larger bacterial populations of the reference, mutant, and flgXe-1 isogenic strains as compared with the other five isogenic strains at both 6 and 9 dpi (Fig. 8). Together with the reactive oxygen species (ROS) results from Figure 1, these findings indicate that the single amino acid polymorphism in the flgII-28 sequence from $X$. euvesicatoria 85-10 allows for evasion of flagellin recognition by the FLS3 receptor in tomato plants.

\section{DISCUSSION}

There have been significant efforts to characterize the variability of flg22 recognition by FLS2, including several studies involving Xanthomonas spp. (Bhattarai et al. 2016; Felix et al.

\section{A $\square$ original $\square$ induced $\square$ suppressed}

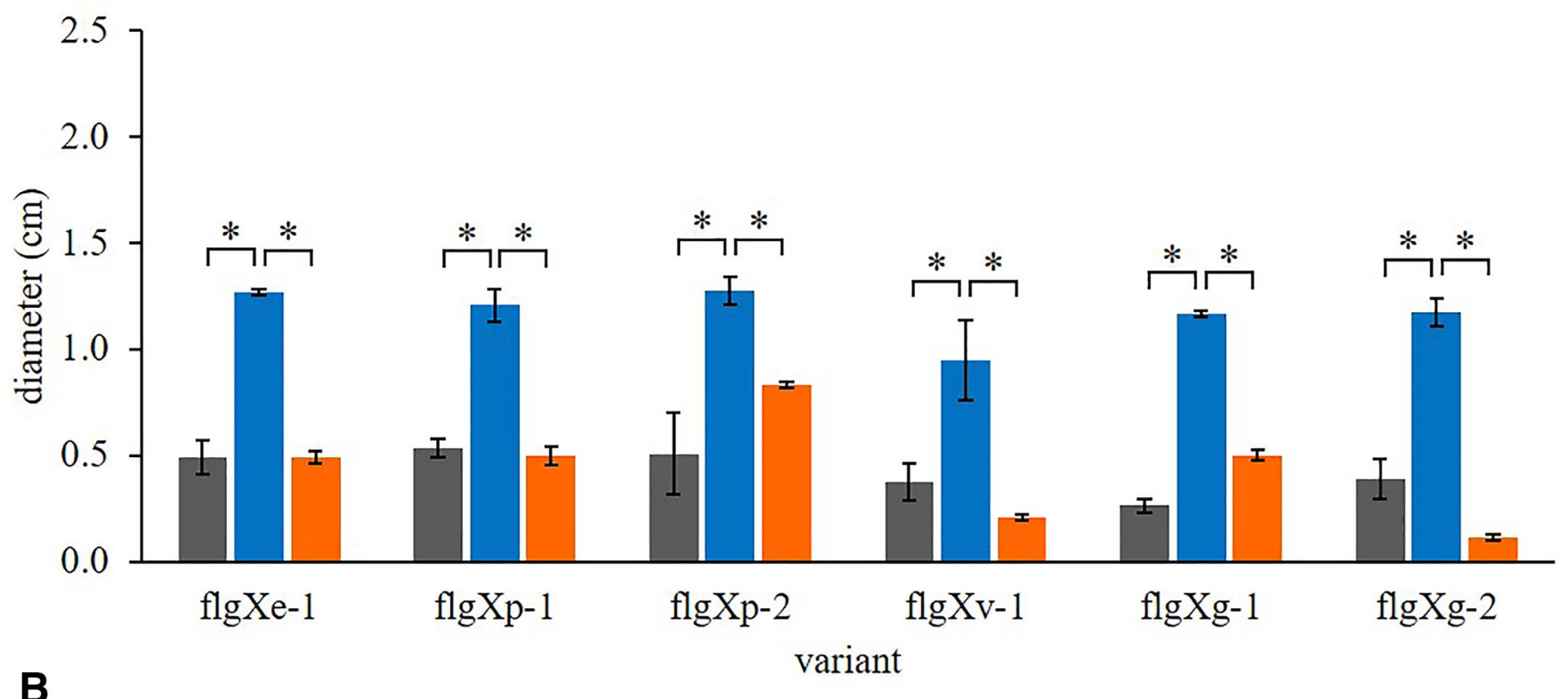

B

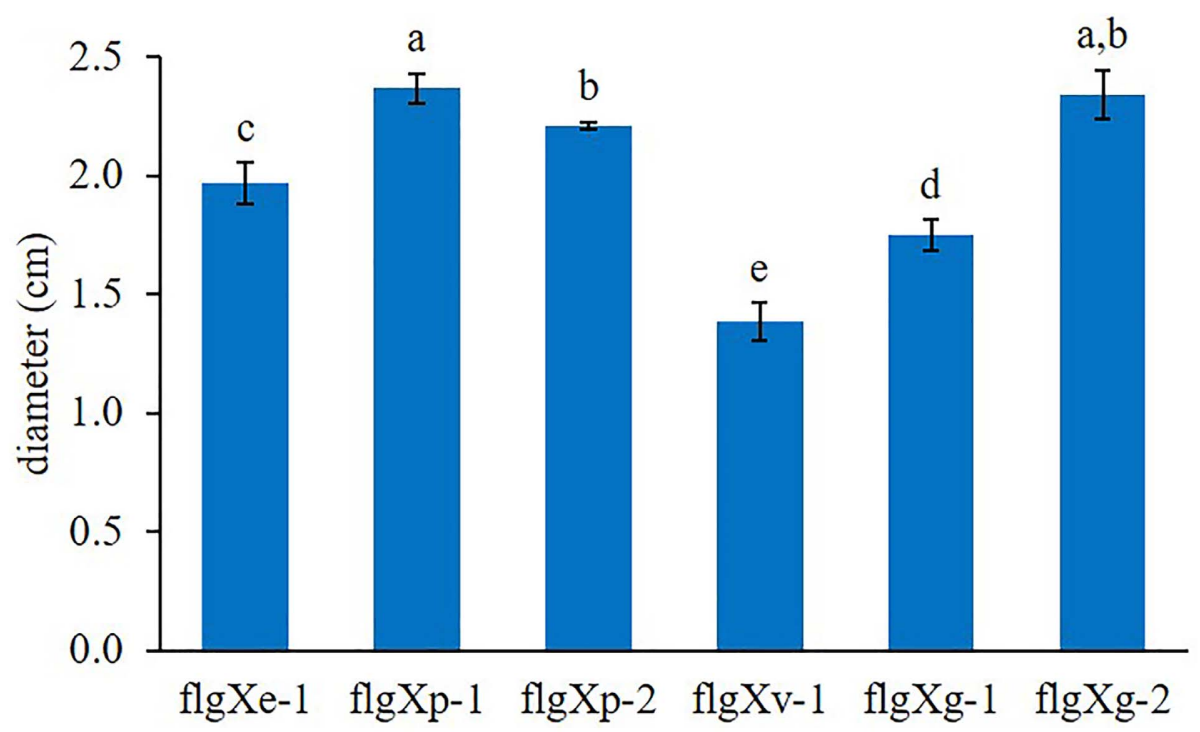

Fig. 6. Comparison of motility for Xanthomonas euvesicatoria isogenic strains expressing different flagellin variants. For each strain, the average motility was assessed prior to any intervention (original), after growth on nutrient media containing the chemoattractant thymidine (induced), or after growth on minimal nutrient media (suppressed). Motility was quantified at A, $24 \mathrm{~h}$ and $\mathbf{B}, 48 \mathrm{~h}$ after inoculation by measuring the diameter of the circular halo formed in the media by the swimming bacteria. Data shown are the means of three independent experiments with error bars indicating the standard error of the means ( $n=4$ replicates per experiment). Asterisks indicate significant differences between original and inductive treatments or inductive and suppressive treatments for each isogenic strain $(P<0.05$, pairwise comparison using Student's $t$ test), while different letters indicate significant differences between the isogenic strains after inductive treatment $(P<0.05$, one-way analysis of variance using least squares method $)$. 
1999; Shi et al. 2016; Sun et al. 2006; Trdá et al. 2014; Wang et al. 2015); however, there have not yet been similar efforts for flgII-28 recognition by FLS3. We found that the oxidative burst response of tomato plants to treatment with Xanthomonas flgII-28 peptides is significantly less than that observed after treatment with a peptide from $P$. syringae, and the flgII28 variant from $X$. euvesicatoria was completely inactive. In addition, there are many examples of altered flg22 sequences that permit phytobacteria such as $R$. solanacearum, $P$. cannabina pv. alisalensis (syn: $P$. syringae pv. maculicola), and Agrobacterium tumefaciens to avoid host recognition by FLS2 (Clarke et al. 2013; Felix et al. 1999; Pfund et al. 2004). Our results indicate that some Xanthomonas spp. may evade both FLS2- and FLS3-mediated immunity, which would support previous work where tomato suspension-cultured cells did not respond to treatment with flagellin derived from $X$. euvesicatoria (syn. X. campestris pv. vesicatoria) (Felix et al. 1999). However, our results indicate that tomato plants can still recognize flgII-28 from other Xanthomonas spp., including $X$. perforans, $X$. vesicatoria, and $X$. gardneri, and that this recognition can reduce the virulence of bacterial strains with these flagellin variants. Given the known differential robustness of ROS responses to flgII-28 treatment (Bhattarai et al. 2016; Cai et al. 2011; Veluchamy et al. 2014), it is possible that

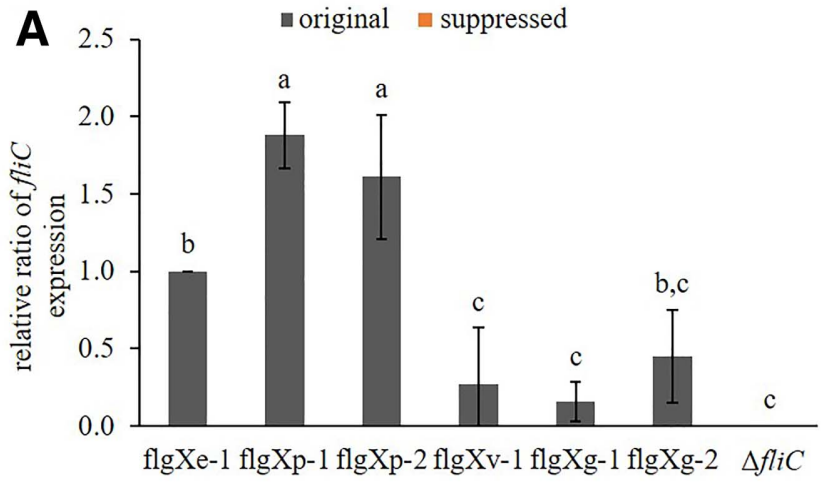

B

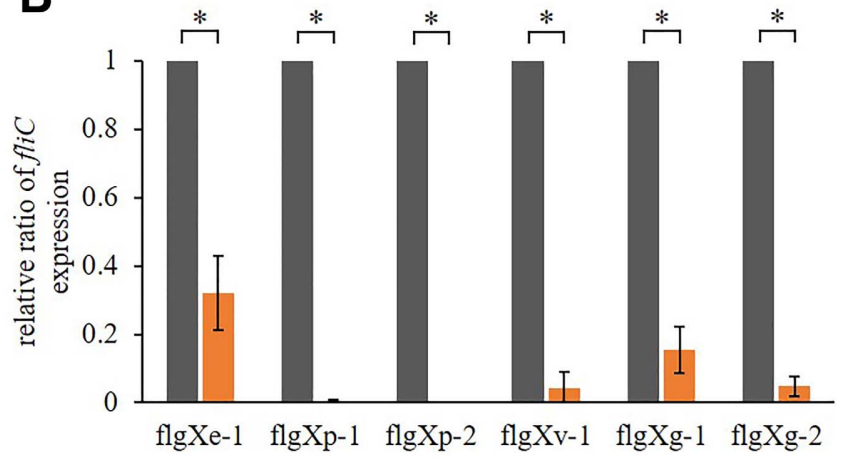

Fig. 7. Comparison of fliC gene expression for Xanthomonas euvesicatoria isogenic strains expressing different flagellin variants. For each strain, bacterial samples were collected prior to any interventions (original) or $24 \mathrm{~h}$ after growth on minimal nutrient media (suppressed). Transcript abundance of $\mathrm{fliC}$ was determined by reverse-transcription quantitative PCR analysis using gyrB as the reference gene for quantification using the $2^{\Delta \Delta C T}$ method. A, Relative ratio of $f l i C$ expression of isogenic strains compared with the $X$. euvesicatoria flgXe-1 strain. B, Relative ratio of fliC expression in strains after suppressive treatments compared with growth under original conditions. Data shown are the means $(n=2$ biological replicates with 4 technical replicates per biological replicate), with error bars indicating the standard deviation. Different letters indicate significant differences between isogenic strains $(P<0.05$, one-way analysis of variance using least squares method) while asterisks indicate significant differences between isogenic and suppression treatments for each variant $(P<0.05$, pairwise comparison using Student's $t$ test). some tomato varieties or other solanaceous species, including potato and pepper, have FLS3 receptor variants that are able to perceive and respond to flgII-28 from $X$. euvesicatoria. Future work could include screening additional germplasm for natural variations in FLS3 activity; if FLS3 variants are discovered, then they could be used to help identify potential ligand binding sites.

Initially, the motility of the Xanthomonas isolates could not be correlated with their flagellin variant; however, less variation was observed after bacterial motility was induced using chemoattractants, with $X$. euvesicatoria and $X$. perforans isolates showing greater motility overall when compared with $X$. vesicatoria and $X$. gardneri isolates. It is known that bacterial motility in soft media ( 0.2 to $0.4 \%$ agar) is related to chemotaxis (Adler 1966), and a previous study observed that $X$. oryzae pv. oryzae isolates were not flagellated when grown on solid agar media but they had flagella visible via electron microscopy when grown on swarming media (0.3\% agar) (Shen et al. 2001). Our chemoattractant assays mirrored these observations, because we also found that bacteria isolated from the ring boundaries of soft agar $(0.2 \%)$ media were more motile compared with when the bacteria were previously grown on solid media. The Xanthomonas isolates in our study did not respond equally to the different potential chemoattractants, although most did respond to treatment with methionine. Surprisingly, the $X$. gardneri isolates did not show chemoattractant behaviors to any of the 10 treatments tested, even though KBase predicted that the $X$. gardneri reference strains JS749-3 (NCBI RefSeq NZ_CP018728) and ICMP 7383 (NCBI RefSeq NZ_CP018731) are likely auxotropic for 4 to 6 of these compounds (i.e., leucine, isoleucine, cysteine, methionine, and potentially arginine and proline). Therefore, we cannot confirm whether the $X$. gardneri isolates exhibited their maximum potential motility, although the greater motility of the isogenic strains expressing the flagellin variants flgXg-1 and flgXg-2 indicates that the reduced motility of $X$. gardneri isolates is not due to reduced activity of flagellin itself.

Bacterial growth under nutrient starvation conditions can result in the loss of motility due to downregulation of flagellumrelated genes (Santander et al. 2014). Similar findings were observed for the wheat pathogen Azospirillum brasilense, where bacterial motility was greatly reduced upon exposure to metabolic stress conditions and nutrient starvation (Sadasivan and Neyra 1985). Previous work found that Xanthomonas swarming motility could not be suppressed using minimal nutrient bacteriological media but, instead, only could revert motile bacteria back to nonmotile after infection and reisolation from a host plant (Kamoun and Kado 1990). In contrast, using the same media recipe described by Kamoun and Kado (1990), we observed that isolates of the four Xanthomonas spp. tested in our study had significantly reduced motility. Although we cannot definitively elucidate the reasons underlying this discrepancy, it is possible that the differences could be due to suppression of swimming $(0.2 \%$ agar) instead of swarming ( $0.3 \%$ agar) motility. Regardless, this additional in vitro method provided an efficient way to evaluate motility suppression phenotypes for a large collection of isolates and isogenic strains.

There are several examples where swarming behaviors have been lost in common laboratory strains due, in part, to the conditions the bacteria experience when grown on standard nutrient agar media with $>1 \%$ agar (Kearns 2010). We have observed swarming behavior on 0.3 to $0.7 \%$ agar media for some of our Xanthomonas isolates that had only limited swimming motility were grown on soft agar $(0.2 \%)$ media. However, this motility was not observed when the same strains were grown on $1.2 \%$ agar media, suggesting that Xanthomonas swarming motility is suppressed by the agar concentrations normally present in growth media. 
We believe that some of the motility differences observed between the isogenic strains can be explained by differences in the expression of $\mathrm{fliC}$ but we cannot explain why the $\mathrm{fliC}$ alleles would be differentially expressed when each gene was integrated into the genome under the control of the native promoter and terminator sequences. Previously, increased $\mathrm{fliC}$ expression and greater motility was observed for $E$. coli present in the outer ring boundary for bacteria grown in soft agar media (Koster et al. 2012); however, each isogenic strain was handled similarly, and the motility and $\mathrm{fliC}$ expression were comparable after independent chemoattractant assays, suggesting that experimental variability or error alone cannot account for these differences. We attempted to evaluate the abundance of flagellin proteins in each isolate; however, there are only a few commercial anti-flagellin antibodies available, none of which were generated using flagellin that was similar to Xanthomonas. We tested two of the available antibodies, both of which are known to recognize flagellin from human pathogens, including Salmonella enterica, E. coli, and Lactobacteria acidophilus (BioLegend number 629701, discontinued; Abcam ab93713); however, neither antibody appeared to recognize flagellin proteins from Xanthomonas spp. (data not shown). Another explanation is that other factors differentially influenced the abundance of $\mathrm{fiC}$ transcripts in the isogenic strains, including altered transcription due to RNA secondary structure (Chełkowska-Pauszek et al. 2021), differential posttranscriptional regulation by small RNAs or RNAbinding proteins (Christopoulou and Granneman in press; Djapgne and Oglesby 2021), or altered RNA processing or degradation of the transcripts (Trinquier et al. 2020). Future work could include additional experiments to test for the presence of other factors differentially influencing the abundance of the different $f i c$ transcripts.

It has been proposed that the history-dependent behaviors of bacterial cells such as "remembered" responses to prior environmental stress could be described as a form of memory (Wolf et al. 2008). The term "response memory" was used to explain the behavior of cells that continued to respond after removal of the stimulus; more specifically, the continued expression of lac protein in E. coli after the removal of lactose from the environment (Lambert and Kussell 2014). Indeed, memory may function as one component of a broader framework of the adaptative behavior observed in how bacteria interact with their ever-changing environment (Pessione 2021). In our study, the similar motility of isolates prior to and after ultracold storage suggests that Xanthomonas spp. may "remember" earlier environmental conditions and have adapted their phenotypes accordingly. These response memories may have differed between isolates obtained from different sources or maintained under different conditions. For example, some isolates may have been preserved soon after collection from plants, while others may have been grown for longer periods of time on standard laboratory ( $>1 \%$ agar) media, both of which could have resulted in altered motility. Our results indicate that future experiments regarding bacterial motility should take prior growth conditions into account.

\section{Conclusions.}

We provide evidence that some Xanthomonas spp. can evade both FLS2- and FLS3-mediated immunity, and that variability in the flagellin sequence may impact bacterial motility. In addition, variable motility between bacterial isolates may be due to external growth parameters, and motility can be induced by chemoattracts while it can be suppressed by nutrient-limiting media. We provide evidence that bacteria can "remember" responses to prior environmental conditions, and that these response memories influence the motility phenotypes of Xanthomonas bacteria.

\section{MATERIALS AND METHODS}

If not specifically noted, experiments were repeated three times with similar results.

\section{Bacterial strains, plasmids, and growth conditions.}

Xanthomonas and E. coli strains and plasmids used in this study are listed in Table 1 and Supplementary Table S2. E. coli strains were cultivated in Luria-Bertani medium at $37^{\circ} \mathrm{C}$. Xanthomonas strains and isolates were grown in PSA medium (2\% [wt/vol] sucrose, $0.5 \%$ [wt/vol] peptone, $0.05 \%$ [wt $/ \mathrm{vol}]$ $\mathrm{K}_{2} \mathrm{HPO}_{4}, 0.05 \%$ [wt/vol] $\mathrm{MgSO}_{4} .7 \mathrm{H}_{2} \mathrm{O}$, and $0.2 \%$ or $1.2 \%$ [wt/vol] agar, depending on the assay), MM (0.7\% [wt/vol] $\mathrm{NaCl}, 0.115 \%$ [wt/vol] $\mathrm{K}_{2} \mathrm{HPO}_{4}, 0.02 \%$ [wt/vol] $\mathrm{KH}_{2} \mathrm{PO}_{4}$,

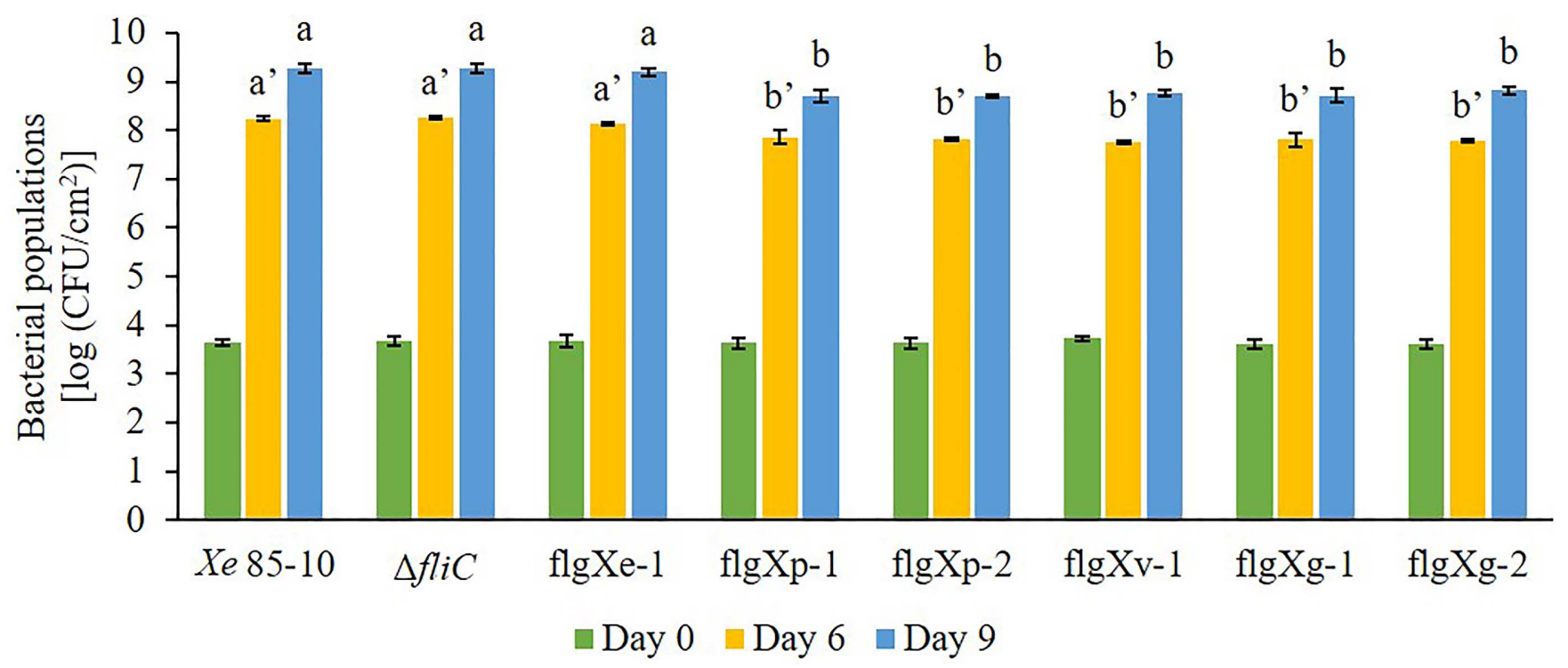

Fig. 8. In planta virulence of Xanthomonas euvesicatoria isogenic strains. Six-week-old 'Brandywine' tomato plants were inoculated by vacuum infiltration with suspensions of each isolate of $5 \times 10^{4} \mathrm{CFU} / \mathrm{ml}$. Bacterial populations were measured at 0 , 6 , and 9 days after inoculation. Data shown are the means of three independent experiments, with error bars indicating the standard error of the means $(n=3$ plants per experiment, with each plant consisting of the average of three replicate samples). Different letters indicate significant differences between populations $(P<0.05$, one-way analysis of variance using least squares method). 
$0.02 \%[\mathrm{wt} / \mathrm{vol}] \mathrm{KCl}, 0.01 \%$ [wt/vol] yeast extract, and $1.2 \%$ [wt/vol] agar), and nutrient agar (NA) $(0.5 \%$ [wt/vol] peptone, $0.3 \%$ [wt/vol] beef extract, $0.5 \%$ [wt/vol] $\mathrm{NaCl}$, and $1.5 \%$ [wt/ vol] agar). The antibiotics kanamycin $(\mathrm{Km}, 50 \mu \mathrm{g} / \mathrm{ml})$, rifampicin (Rif, 25 to $50 \mu \mathrm{g} / \mathrm{ml}$ ), and tetracycline $(15 \mu \mathrm{g} / \mathrm{ml})$ were added as required.

\section{Materials.}

Peptides were synthesized by Genscript (Piscataway, NJ, U.S.A.) at $>90 \%$ purity. Primers were synthesized by Integrated DNA Technologies (Coralville, IA, U.S.A.) and are listed in Supplementary Table S4. All peptides were resuspended in water. Seeds of tomato (Solanum lycopersicum 'Brandywine') were obtained from Peaceful Valley Farm \& Garden Supply (Grass Valley, CA, U.S.A.). Seedlings were grown in Berger BM6 soilless mix supplemented with vermiculite and osmocote 15-9-12 and kept in a greenhouse (25 and $21^{\circ} \mathrm{C}$ day and night temperatures, respectively) without supplemental lighting.

\section{Sequence comparisons.}

A phylogenetic analysis was performed using six flagellin protein sequences obtained in October 2017 from the NCBI: flgXe-1 (WP_007962409.1), flgXp-1 (WP_008575952.1), flgXp-2 (WP_046935349.1), flgXv-1 (WP_011037106.1), flgXg-1 (WP_046932599.1), and flgXg-2 (WP_006452268.1). Protein alignments were made using ClustalW and a maximum-likelihood tree was generated using MEGA X v10.0.2 (Kumar et al. 2018), with pairwise distances estimated using a JTT model and with 1,000 bootstrap replicates. An estimation of the pairwise percent similarity between six flagellin protein sequences was performed and an identity matrix was generated using MEGA X.

\section{Oxidative burst assays.}

Quantitation of ROS production for tomato plants was performed as previously described (Hind et al. 2016). Leaf disks of 6-week-old tomato plants were punched with a number 2 cork borer (4 $\mathrm{mm}$ in diameter) and floated adaxial side up overnight in $200 \mu \mathrm{l}$ of distilled water in individual wells of a 96-well microassay plate. Four plants were used for each treatment, with three replicate disks sampled per plant. The water was replaced $16 \mathrm{~h}$ later with a solution containing $100 \mathrm{nM}$ peptide (or water for the controls), luminol at $34 \mathrm{ug} / \mathrm{ml}$ (Millipore Sigma-Aldrich, St. Louis, MO, U.S.A.), and horseradish peroxidase at $20 \mu \mathrm{g} / \mathrm{ml}$ (type VI; Millipore Sigma-Aldrich). The luminescence was measured using a FilterMax F5 plate reader (Molecular Devices, San Jose, CA, U.S.A.) for $45 \mathrm{~min}$ at an interval of $3 \mathrm{~min}$ per read, for a total of 16 reads. Each read had an integration time of 1,250 ms. For each treatment, the total ROS production was calculated by summing the relative light units from the 16 reads. The peptides used for the treatments include three variants of flg22: the standard variant from $P$. aeruginosa (Felix et al. 1999); a consensus variant from $X$. euvesicatoria, X. perforans, and $X$. vesicatoria; and the variant from $X$. gardneri; and four variants of flgII-28: the standard variant from $P$. syringae pv. tomato T1 (Clarke et al. 2013), one variant from X. campestris pv. campestris, the consensus variant from multiple Xanthomonas spp., and one variant from $X$. euvesicatoria.

\section{Bacterial assays.}

Motility assays (outlined in Supplementary Fig. S1) were performed using PSA, and plates were inoculated from individual colonies of bacteria grown for 3 days on PSA $1.2 \%$ (wt/vol) agar plates at $28^{\circ} \mathrm{C}$. Four individual spots per plate were penetrated using sterile toothpicks inoculated with bacteria. Plates were incubated at $28^{\circ} \mathrm{C}$ for $48 \mathrm{~h}$ and motility was assessed quantitatively by measuring the diameters of the circular halos formed within the media by the swimming bacteria. Each experiment was repeated three times, for a total of 12 colonies assessed per treatment per isolate. Box plots were used to confirm the lack of outliers, and the Shapiro-Wilk normality test was used to confirm that all data were normally distributed.

Attraction assays were performed using the following chemoattracts: methionine, glutamic acid, thiamine, thymidine, arginine, alanine, leucine, isoleucine, cysteine, or proline. To prepare attraction plates, $5 \mu \mathrm{l}$ of each $0.1 \mathrm{M}$ chemoattractant solution was added to the center of the PSA $0.2 \%$ (wt/vol) agar plates before agar had completely solidified. Three equidistant positions were marked $2 \mathrm{~cm}$ away from the chemoattractant spot and the media were inoculated with bacteria at these locations. Bacteria were grown for $72 \mathrm{~h}$; then, cells at the leading edge of the swimming halo were used to streak single colonies on PSA $1.2 \%$ (wt/vol) agar plates. Swimming assays were then performed using the resulting single colonies in order to measure postinduction motility.

Suppression assays were performed using MM (Kamoun and Kado 1990) with $1.2 \%$ (wt/vol) agar. Single colonies from PSA agar plates were used to inoculate the MM plates and then incubated at $28^{\circ} \mathrm{C}$ for $96 \mathrm{~h}$. The resulting single colonies were used for motility assays in order to measure the effects of postattraction suppression of motility.

\section{Construction of gene deletion mutant and complementation strains of Xanthomonas.}

To create the $f l i C$ knockout mutant $(\triangle f l i C)$, a marker exchange strategy was applied using the suicide vector $\mathrm{pK} 18 \mathrm{mobsacB}$ via allelic homologous recombination (Schäfer et al. 1994). The upstream (712 bp) and downstream (516 bp) regions adjacent to the $f i C$ coding sequence were amplified from $X$. euvesicatoria 85-10 genomic DNA using the two primer pairs (P0071/P0074 and P0072/P0073) (Supplementary Table S4). The tetracycline resistance gene was used for allelic exchange and amplified from plasmid pRK415 using the primer pair P0075/P0076. The DNA was amplified using Platinum SuperFi DNA Polymerase (Invitrogen, Carlsbad, CA, U.S.A.), the PCR products were purified (E.Z.N.A. Microelute Cycle-Pure Kit, Omega Bio-Tek, Norcross, GA, U.S.A.), and the purified DNA was digested with the corresponding restriction enzymes for cloning into pK18mobsacB, resulting in the plasmid pK18 $\mathrm{fliC}$ (Table 1 ). After sequence confirmation, the plasmid was conjugated from $E$. coli $\mathrm{S} 17-1 \lambda$ pir into $X$. euvesicatoria $85-10$ by biparental mating. NA plates containing Rif and $\mathrm{Km}$ were used to select bacteria that had undergone the first crossover event. Colonies were then plated on PSA containing $10 \%(\mathrm{wt} / \mathrm{vol})$ sucrose to select for those colonies having undergone the second crossover event. The putative $X$. euvesicatoria 85$10 \triangle \mathrm{fliC}$ candidates were confirmed by colony PCR (Supplementary Fig. S2B), Sanger sequencing of the modified genomic region, and motility assays (Supplementary Fig. S3A and B).

For complementation, the upstream (712 bp) and downstream (516 bp) regions adjacent to the $f i C$ coding sequence were amplified from $X$. euvesicatoria 85-10 genomic DNA using the two primer pairs P0071/P0074 and P0072/P0073 (Supplementary Table S4). Each of the $f l i C$ alleles were amplified using the following primer pairs for the corresponding strains: P0065/ P0066 for $f l i C_{X e-1}$ from X. euvesicatoria $85-10$, for $f l C_{X p-1}$ from $X$. perforans $91-118$, and for $f l C_{X p-2}$ from $X$. perforans $17-12$; $\mathrm{P} 0070 / \mathrm{P} 0066$ for $f l i C_{X v-1}$ from $X$. vesicatoria ATCC 35937; and $\mathrm{P} 0067 / \mathrm{P} 0068$ for $f \mathrm{C}_{X g-1}$ from $X$. gardneri SM177-10 and for $f_{i i C_{X g-2}}$ from $X$. gardneri ATCC 19865. The DNA was cloned into pK18mobsacB and the plasmids were conjugated into the $X$. euvesicatoria $85-10 \Delta f l i C$ strain, as described above. After selection for the second recombination event, candidates for the isogenic $\mathrm{fliC}$ complemented strains were confirmed by colony PCR (Supplementary Fig. S2D) and Sanger sequencing of the modified genomic region. 


\section{RNA extraction and reverse transcription of RNA templates.}

Bacteria were treated as described above and as outlined in Supplementary Fig. S1. Bacteria were harvested and stored at $-80^{\circ} \mathrm{C}$ until RNA was extracted using TRIzol Reagent (Invitrogen), and potential DNA contamination was removed using Turbo DNA-free Kit (Invitrogen). Total RNA $(1 \mu \mathrm{g})$ was used to prepare cDNA using SuperScript III First-Strand Synthesis System for reverse-transcription PCR (RT-PCR) (Invitrogen).

\section{Quantitative RT-PCR.}

Primers used to amplify the target $f l i C$ gene were designed as follows: the alleles that represent the six variants were aligned, and primers were designed to target consensus sequences while avoiding any polymorphisms. Primers used to amplify the endogenous housekeeping genes $t m R N A$ and $g y r B$ were described previously (Yan et al. 2019). Primer sets P0236/P0237, P0247/P0248, and P0275/P0276 (Supplementary Table S4) were used to amplify $f l i$, gyrB, and $t m R N A$, respectively. Each $10-\mu l$ quantitative PCR mixture contained $5 \mu$ of PowerUp SYBR Green $2 \times$ Master Mix (Applied Biosystems), $1 \mu \mathrm{l}$ each of the primers (final concentration of $800 \mathrm{nM}$ ), $2 \mu \mathrm{l}$ of nuclease-free water, and $1 \mu \mathrm{l}$ of 1:10 diluted cDNA template. Quantitative RT-PCR was performed on a QuantStudio 3 Real-Time PCR System (Applied Biosystems) using fast cycling conditions. Data were normalized to tmRNA or gyrB, and analyzed using the $2^{\Delta \Delta \mathrm{CT}}$ method (Schmittgen and Livak 2008). Relative ratios of $\mathrm{fliC}$ expression were calculated by comparing the motility under different treatments or by comparing the motility of the different isogenic strains to the control strain.

\section{Bacterial virulence assays.}

Bacterial isolates were grown on PSA medium for 2 days prior to inoculation, and bacterial suspensions containing bacteria at $5 \times 10^{4} \mathrm{CFU} / \mathrm{ml}$ were prepared in a solution containing $10 \mathrm{mM}$ $\mathrm{MgCl}_{2}$ and $0.02 \%$ (vol/vol) Silwet L-77 (bioWORLD, Dublin, $\mathrm{OH}$, U.S.A.). Six-week-old tomato plants were immersed in the bacterial suspension and vacuum infiltrated twice for 5 min

Table 1. Bacterial strains and plasmids used in this study, with their relevant characteristics and the reference or source

\begin{tabular}{|c|c|c|}
\hline Strains and plasmids & Relevant characteristics $^{\mathbf{a}}$ & Reference, source \\
\hline \multicolumn{3}{|l|}{ Strains } \\
\hline \multicolumn{3}{|l|}{ Escherichia coli } \\
\hline $\mathrm{DH} 5 \alpha$ & $\begin{array}{l}\lambda \text {-f80d lac ZDM15 D (lac ZYA-arg F) U169 } \\
\quad \text { recAl endA hsdR17 }\left(\mathrm{r}_{\mathrm{K}}^{-} \mathrm{m}_{\mathrm{k}}^{-}\right) \text {supE44 thi } \\
\quad 1 \text { gyrA relAl }\end{array}$ & Laboratory collection \\
\hline S17-1 $\lambda$ pir & $\begin{array}{l}\text { RP4-2 Tc::Mu-Km::Tn7 pro hsdR recA Tra+ } \\
\quad \text { used as mobilizing strain }\end{array}$ & Simon et al. 1983 \\
\hline \multicolumn{3}{|l|}{$\begin{array}{l}\text { Xanthomonas } \\
\text { euvesicatoria }\end{array}$} \\
\hline $85-10$ & Wild type; $f l i C_{85-10}, \mathrm{Rif}^{\mathrm{r}}$ & Laboratory collection \\
\hline $85-10 \Delta f l i C$ & 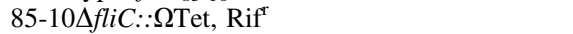 & This study \\
\hline $85-10$ fliC $_{\mathrm{Xe}-1}$ & 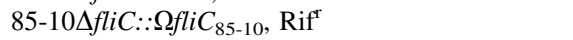 & This study \\
\hline $85-10$ fli $_{\mathrm{Xp}-1}$ & 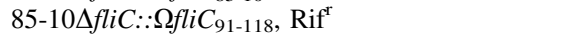 & This study \\
\hline $85-10$ fli $_{\mathrm{Xp}-2}$ & 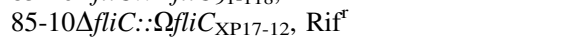 & This study \\
\hline $85-10$ fli $_{\mathrm{Xv}-1}$ & $85-10 \Delta$ fliC:: $\Omega$ flic 1111 (ATCC 35937), Rif $^{\mathrm{r}}$ & This study \\
\hline $85-10 \mathrm{fli}_{\mathrm{Xg}-1}$ & $85-10 \Delta{\text { fliC }:: \Omega \text { fli }_{\mathrm{SM} 177-10}, \mathrm{Rif}^{\mathrm{T}}}^{\mathrm{T}}$ & This study \\
\hline $85-10$ fli $_{\mathrm{Xg}-2}$ & 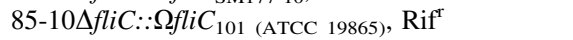 & This study \\
\hline \multicolumn{3}{|l|}{$X$. vesicatoria } \\
\hline 1111 (ATCC 35937) & $f l i C_{1111}$ & Potnis et al. 2011 \\
\hline \multicolumn{3}{|l|}{$X$. perforans } \\
\hline $91-118$ & fliC $_{91-118}$ & Potnis et al. 2011 \\
\hline XP17-12 & $f l i C_{X P} 17-12$ & Schwartz et al. 2015 \\
\hline \multicolumn{3}{|l|}{ X. gardneri } \\
\hline SM177-10 & fli $_{S M 177-10}$ & Schwartz et al. 2015 \\
\hline 101 (ATCC 19865) & fliC $_{101 \text { (ATCC 19865) }}$ & Potnis et al. 2011 \\
\hline \multicolumn{3}{|l|}{ Plasmids } \\
\hline pK18mobsacB & $\begin{array}{l}\text { Allelic exchange suicide vector, } \mathrm{Km}^{\mathrm{r}} \text {, } s a c B \text {, } \\
\mathrm{Tra}^{-}, \mathrm{Mob}^{+}\end{array}$ & Schäfer et al. 1994 \\
\hline $\mathrm{pK} 18 \Delta f l i C$ & $\begin{array}{l}\mathrm{Km}^{\mathrm{r}}, \mathrm{Tc}^{\mathrm{r}} \text {, pK18mobsacB, } \Delta f l i C \text { (in frame) } \\
\quad \text { replaced with } T c\end{array}$ & This study \\
\hline pK18fliC $85-10$ & $\begin{array}{l}\text { pK18mobsacB containing } f l i C_{85-10} \text {, including } \\
712 \text { bp upstream and } 516 \text { bp downstream of } \\
\text { the } f l i C_{85-10} \text { coding region }\end{array}$ & This study \\
\hline pK18fliC $C_{91-118}$ & $\begin{array}{l}\text { pK18mobsacB containing } f l i C_{91-118} \text {, including } \\
712 \mathrm{bp} \text { upstream and } 516 \mathrm{bp} \text { downstream of } \\
\text { the } \text { fli }_{85-10} \text { coding region }\end{array}$ & This study \\
\hline $\mathrm{pK} 18 f l i C_{\mathrm{XP} 17-12}$ & $\begin{array}{l}\text { pK18mobsacB containing } f l i C_{\mathrm{XP17-12}} \text {, including } \\
712 \mathrm{bp} \text { upstream and } 516 \mathrm{bp} \text { downstream of } \\
\text { the } f l i C_{85-10} \text { coding region }\end{array}$ & This study \\
\hline $\begin{array}{l}\text { pK18fli } C_{1111}(\text { ATCC } \\
\text { 35937) }\end{array}$ & $\begin{array}{l}\text { pK18mobsacB containing } f l i C_{1111(\mathrm{ATCC}} 35937 \text { ), } \\
\text { including } 712 \text { bp upstream and } 516 \mathrm{bp} \\
\text { downstream of the } f l i C_{85-10} \text { coding region }\end{array}$ & This study \\
\hline $\mathrm{pK} 18 f l i C_{\mathrm{SM} 177-10}$ & $\begin{array}{l}\text { pK18mobsacB containing } f l i C_{\mathrm{SM} 177-10} \text {, including } \\
712 \mathrm{bp} \text { upstream and } 516 \mathrm{bp} \text { downstream of } \\
\text { the } f l i C_{85-10} \text { coding region }\end{array}$ & This study \\
\hline pK18fliC $C_{101}$ (ATCC 19865) & $\begin{array}{l}\left.\text { pK18mobsac } B \text { containing } f l i C_{101(\mathrm{ATCC}} 19865\right) \\
\text { including } 712 \mathrm{bp} \text { upstream and } 516 \mathrm{bp} \\
\text { downstream of the } f l i C_{85-10} \text { coding region }\end{array}$ & This study \\
\hline pRK415 & Broad-host-range vector, $\mathrm{RK} 2$ ori, $\mathrm{Tc}^{\mathrm{r}}$ & Keen et al. 1988 \\
\hline
\end{tabular}

${ }^{\mathrm{a}} \mathrm{Rif}^{\mathrm{r}}, \mathrm{Km}^{\mathrm{r}}$, and $\mathrm{Tc}^{\mathrm{r}}$ indicate resistant to rifampicin, kanamycin, and tetracycline, respectively. 
each. Inoculated plants were kept in a greenhouse (12-h day length, with day and night temperatures of 27 and $21^{\circ} \mathrm{C}$, respectively) until sampled to determine bacterial populations. Leaf disks were punched with a number 3 cork borer $(9 \mathrm{~mm}$ in diameter) from fully expanded leaflets; leaf 2 was used for 0-dpi samples, leaf 3 for 6-dpi samples, and leaf 4 for 9-dpi samples. Two sets of leaf disks were sampled from each plant for replication at each time point, and three plants were inoculated for each treatment. Leaf disks were macerated in $10 \mathrm{mM} \mathrm{MgCl}$, serially diluted, and plated on PSA medium supplemented with Rif at 25 to $50 \mu \mathrm{g} / \mathrm{ml}$. Bacterial colonies were counted 2 days after plating.

\section{Data availability.}

Datasets supporting the conclusions of this article are included within the article and its supplementary files. Bacterial isolates will be made available upon request.

\section{ACKNOWLEDGMENTS}

We thank the staff at the Plant Care Facility at the University of Illinois for assistance with plant care, and G. Martin at the Boyce Thompson Institute and J. Jones at the University of Florida for providing the Xanthomonas isolates.

\section{AUTHOR-RECOMMENDED INTERNET RESOURCE}

NCBI: https://www.ncbi.nlm.nih.gov/

\section{LITERATURE CITED}

Adler, J. 1966. Chemotaxis in bacteria. Science 153:708-716.

An, S. Q., Allan, J. H., McCarthy, Y., Febrer, M., Dow, J. M., and Ryan, R. P. 2014. The PAS domain-containing histidine kinase RpfS is a second sensor for the diffusible signal factor of Xanthomonas campestris. Mol. Microbiol. 92:586-597.

Arkin, A. P., Cottingham, R. W., Henry, C. S., Harris, N. L., Stevens, R. L., Maslov, S., Dehal, P., Ware, D., Perez, F., Canon, S., Sneddon, M. W., Henderson, M. L., Riehl, W. J., Murphy-Olson, D., Chan, S. Y., Kamimura, R. T., Kumari, S., Drake, M. M., Brettin, T. S., Glass, E. M., Chivian, D., Gunter, D., Weston, D. J., Allen, B. H., Baumohl, J., Best, A. A., Bowen, B., Brenner, S. E., Bun, C. C., Chandonia, J. M., Chia, J. M., Colasanti, R., Conrad, N., Davis, J. J., Davison, B. H., DeJongh, M., Devoid, S., Dietrich, E., Dubchak, I., Edirisinghe, J. N., Fang, G., Faria, J. P., Frybarger, P. M., Gerlach, W., Gerstein, M., Greiner, A., Gurtowski, J., Haun, H. L., He, F., Jain, R., Joachimiak, M. P., Keegan, K. P., Kondo, S., Kumar, V., Land, M. L., Meyer, F., Mills, M., Novichkov, P. S., Oh, T., Olsen, G. J., Olson, R., Parrello, B., Pasternak, S., Pearson, E., Poon, S. S., Price, G. A., Ramakrishnan, S., Ranjan, P., Ronald, P. C., Schatz, M. C., Seaver, S. M. D., Shukla, M., Sutormin, R. A., Syed, M. H., Thomason, J., Tintle, N. L., Wang, D., Xia, F., Yoo, H., Yoo, S., and Yu, D. 2018. KBase: The United States Department of Energy Systems Biology Knowledgebase. Nat. Biotechnol. 36:566-569.

Ausubel, F. M. 2005. Are innate immune signaling pathways in plants and animals conserved? Nat. Immunol. 6:973-979.

Bhattarai, K., Louws, F. J., Williamson, J. D., and Panthee, D. R. 2016. Differential response of tomato genotypes to Xanthomonas-specific pathogen-associated molecular patterns and correlation with bacterial spot (Xanthomonas perforans) resistance. Hortic. Res. 3:16035.

Cai, R., Lewis, J., Yan, S., Liu, H., Clarke, C. R., Campanile, F., Almeida, N. F., Studholme, D. J., Lindeberg, M., Schneider, D., Zaccardelli, M. Setubal, J. C., Morales-Lizcano, N. P., Bernal, A., Coaker, G., Baker, C., Bender, C. L., Leman, S., and Vinatzer, B. A. 2011. The plant pathogen Pseudomonas syringae pv. tomato is genetically monomorphic and under strong selection to evade tomato immunity. PLoS Pathog. 7:e1002130.

Chatterjee, A., Cui, Y., Chakrabarty, P., and Chatterjee, A. K. 2010. Regulation of motility in Erwinia carotovora subsp. carotovora: Quorumsensing signal controls FlhDC, the global regulator of flagellar and exoprotein genes, by modulating the production of RsmA, an RNAbinding protein. Mol. Plant-Microbe Interact. 23:1316-1323.

Che, F. S., Nakajima, Y., Tanaka, N., Iwano, M., Yoshida, T., Takayama, S., Kadota, I., and Isogai, A. 2000. Flagellin from an incompatible strain of Pseudomonas avenae induces a resistance response in cultured rice cells. J. Biol. Chem. 275:32347-32356.

Chełkowska-Pauszek, A., Kosiński, J. G., Marciniak, K., Wysocka, M. Bạkowska-Żywicka, K., and Żywicki, M. 2021. The role of RNA secondary structure in regulation of gene expression in bacteria. Int. J. Mol. Sci. 22:7845.

Christopoulou, N., and Granneman, S. The role of RNA-binding proteins in mediating adaptive responses in Gram-positive bacteria. FEBS J. In press.

Clarke, C. R., Chinchilla, D., Hind, S. R., Taguchi, F., Miki, R., Ichinose Y., Martin, G. B., Leman, S., Felix, G., and Vinatzer, B. A. 2013. Allelic variation in two distinct Pseudomonas syringae flagellin epitopes modulates the strength of plant immune responses but not bacterial motility. New Phytol. 200:847-860.

Djapgne, L., and Oglesby, A. G. 2021. Impacts of small RNAs and their chaperones on bacterial pathogenicity. Front. Cell. Infect. Microbiol. 11:604511.

Felix, G., Duran, J. D., Volko, S., and Boller, T. 1999. Plants have a sensitive perception system for the most conserved domain of bacterial flagellin. Plant J. 18:265-276.

Fliegmann, J., and Felix, G. 2016. Immunity: Flagellin seen from all sides. Nat. Plants 2:16136.

Gosztolai, A., and Barahona, M. 2020. Cellular memory enhances bacterial chemotactic navigation in rugged environments. Commun. Phys. 3:47.

Hind, S. R., Strickler, S. R., Boyle, P. C., Dunham, D. M., Bao, Z., O’Doherty, I. M., Baccile, J. A., Hoki, J. S., Viox, E. G., Clarke, C. R., Vinatzer, B. A., Schroeder, F. C., and Martin, G. B. 2016 Tomato receptor FLAGELLIN-SENSING 3 binds flgII-28 and activates the plant immune system. Nat. Plants 2:16128.

Huang, J. 1986. Ultrastructure of bacterial penetration in plants. Annu. Rev. Phytopathol. 24:141-157.

Jacques, M.-A., Arlat, M., Boulanger, A., Boureau, T., Carrère, S., Cesbron, S., Chen, N. W., Cociancich, S., Darrasse, A., Denancé, N., FischerLe Saux, M., Gagnevin, L., Koebnik, R., Lauber, E., Noël, L. D., Pieretti, I., Portier, P., Pruvost, O., Rieux, A., Robène, I., Royer, M., Szurek, B., Verdier, V., and Vernière, C. 2016. Using ecology, physiology, and genomics to understand host specificity in Xanthomonas. Annu. Rev. Phytopathol. 54:163-187.

Jones, J., Pohronezny, K., Stall, R., and Jones, J. 1986. Survival of Xanthomonas campestris pv. vesicatoria in Florida on tomato crop residue, weeds, seeds, and volunteer tomato plants. Phytopathology 76:430-434.

Josenhans, C., and Suerbaum, S. 2002. The role of motility as a virulence factor in bacteria. Int. J. Med. Microbiol. 291:605-614.

Kamoun, S., and Kado, C. I. 1990. Phenotypic switching affecting chemotaxis, xanthan production, and virulence in Xanthomonas campestris. Appl. Environ. Microbiol. 56:3855-3860.

Kearns, D. B. 2010. A field guide to bacterial swarming motility. Nat Rev. Microbiol. 8:634-644.

Keen, N. T., Tamaki, S., Kobayashi, D., and Trollinger, D. 1988. Improved broad-host-range plasmids for DNA cloning in gramnegative bacteria. Gene 70:191-197.

Kordes, A., Grahl, N., Koska, M., Preusse, M., Arce-Rodriguez, A., Abraham, W.-R., Kaever, V., and Häussler, S. 2019. Establishment of an induced memory response in Pseudomonas aeruginosa during infection of a eukaryotic host. ISME J. 13:2018-2030.

Koster, D. A., Mayo, A., Bren, A., and Alon, U. 2012. Surface growth of a motile bacterial population resembles growth in a chemostat. J. Mol. Biol. 424:180-191.

Kumar, S., Stecher, G., Li, M., Knyaz, C., and Tamura, K. 2018. MEGA $\mathrm{X}$ : Molecular evolutionary genetics analysis across computing platforms. Mol. Biol. Evol. 35:1547-1549.

Kumar Verma, R., Samal, B., and Chatterjee, S. 2018. Xanthomonas oryzae pv. oryzae chemotaxis components and chemoreceptor Mcp2 are involved in the sensing of constituents of xylem sap and contribute to the regulation of virulence-associated functions and entry into rice. Mol. Plant Pathol. 19:2397-2415.

Lambert, G., and Kussel, E. 2014. Memory and fitness optimization of bacteria under fluctuating environments. PLoS Genet. 10:e1004556.

Matilla, M. A., and Krell, T. 2018. The effect of bacterial chemotaxis on host infection and pathogenicity. FEMS Microbiol. Rev. 42:fux052.

Meindl, T., Boller, T., and Felix, G. 2000. The bacterial elicitor flagellin activates its receptor in tomato cells according to the address-message concept. Plant Cell 12:1783-1794.

Merritt, P. M., Danhorn, T., and Fuqua, C. 2007. Motility and chemotaxis in Agrobacterium tumefaciens surface attachment and biofilm formation. J. Bacteriol. 189:8005-8014.

Moreira, L. M., Facincani, A. P., Ferreira, C. B., Ferreira, R. M., Ferro, M. I., Gozzo, F. C., de Oliveira, J. C., Ferro, J. A., and Soares, M. R. 
2015. Chemotactic signal transduction and phosphate metabolism as adaptive strategies during citrus canker induction by Xanthomonas citri. Funct. Integr. Genomics 15:197-210.

Moroz, N., and Tanaka, K. 2020. FlgII-28 is a major flagellin-derived defense elicitor in potato. Mol. Plant-Microbe Interact. 33:247-255.

Naito, K., Taguchi, F., Suzuki, T., Inagaki, Y., Toyoda, K., Shiraishi, T., and Ichinose, Y. 2008. Amino acid sequence of bacterial microbeassociated molecular pattern flg22 is required for virulence. Mol. Plant-Microbe Interact. 21:1165-1174.

Ottemann, K. M., and Miller, J. F. 1997. Roles for motility in bacterialhost interactions. Mol. Microbiol. 24:1109-1117.

Parys, K., Colaianni, N. R., Lee, H. S., Hohmann, U., Edelbacher, N., Trgovcevic, A., Blahovska, Z., Lee, D., Mechtler, A., Muhari-Portik, Z., Madalinski, M., Schandry, N., Rodríguez-Arévalo, I., Becker, C., Sonnleitner, E., Korte, A., Bläsi, U., Geldner, N., Hothorn, M., Jones, C. D., Dangl, J. L., and Belkhadir, Y. 2021. Signatures of antagonistic pleiotropy in a bacterial flagellin epitope. Cell Host Microbe 29: 620-634.e9.

Pessione, E. 2021. The less expensive choice: Bacterial strategies to achieve successful and sustainable reciprocal interactions. Front. Microbiol. 11:571417.

Pfund, C., Tans-Kersten, J., Dunning, F. M., Alonso, J. M., Ecker, J. R., Allen, C., and Bent, A. F. 2004. Flagellin is not a major defense elicitor in Ralstonia solanacearum cells or extracts applied to Arabidopsis thaliana. Mol. Plant-Microbe Interact. 17:696-706.

Potnis, N., Krasileva, K., Chow, V., Almeida, N. F., Patil, P. B., Ryan, R. P., Sharlach, M., Behlau, F., Dow, J. M., Momol, M., White, F. F., Preston, J. F., Vinatzer, B. A., Koebnik, R., Setubal, J. C., Norman, D. J., Staskawicz, B. J., and Jones, J. B. 2011. Comparative genomics reveals diversity among xanthomonads infecting tomato and pepper. BMC Genomics 12:146.

Potnis, N., Timilsina, S., Strayer, A., Shantharaj, D., Barak, J. D., Paret, M. L., Vallad, G. E., and Jones, J. B. 2015. Bacterial spot of tomato and pepper: Diverse Xanthomonas species with a wide variety of virulence factors posing a worldwide challenge. Mol. Plant Pathol. 16:907-920.

Roberts, R., Liu, A. E., Wan, L., Geiger, A. M., Hind, S. R., Rosli, H. G., and Martin, G. B. 2020. Molecular characterization of differences between the tomato immune receptors flagellin sensing 3 and flagellin sensing 2. Plant Physiol. 183:1825-1837.

Sadasivan, L., and Neyra, C. A. 1985. Flocculation in Azospirillum brasilense and Azospirillum lipoferum: Exopolysaccharides and cyst formation. J. Bacteriol. 163:716-723.

Saijo, Y., Loo, E. P., and Yasuda, S. 2018. Pattern recognition receptors and signaling in plant-microbe interactions. Plant J. 93:592-613.

Santander, R. D., Oliver, J. D., and Biosca, E. G. 2014. Cellular, physiological, and molecular adaptive responses of Erwinia amylovora to starvation. FEMS Microbiol. Ecol. 88:258-271.

Schäfer, A., Tauch, A., Jäger, W., Kalinowski, J., Thierbach, G., and Pühler, A. 1994. Small mobilizable multi-purpose cloning vectors derived from the Escherichia coli plasmids pK18 and pK19: Selection of defined deletions in the chromosome of Corynebacterium glutamicum. Gene 145:69-73.

Schmittgen, T. D., and Livak, K. J. 2008. Analyzing real-time PCR data by the comparative $\mathrm{C}_{\mathrm{T}}$ method. Nat. Protoc. 3:1101-1108.

Schwartz, A. R., Potnis, N., Timilsina, S., Wilson, M., Patané, J., Martins, J., Jr., Minsavage, G. V., Dahlbeck, D., Akhunova, A., Almeida, N., Vallad, G. E., Barak, J. D., White, F. F., Miller, S. A., Ritchie, D., Goss, E., Bart, R. S., Setubal, J. C., Jones, J. B., and Staskawicz, B. J. 2015. Phylogenomics of Xanthomonas field strains infecting pepper and tomato reveals diversity in effector repertoires and identifies determinants of host specificity. Front. Microbiol. 6:535.

Shen, Y., Chern, M., Silva, F. G., and Ronald, P. 2001. Isolation of a Xanthomonas oryzae pv. oryzae flagellar operon region and molecular characterization of flhF. Mol. Plant-Microbe Interact. 14:204-213.
Shen, Y., and Ronald, P. 2002. Molecular determinants of disease and resistance in interactions of Xanthomonas oryzae pv. oryzae and rice. Microbes Infect. 4:1361-1367.

Shi, Q., Febres, V. J., Jones, J. B., and Moore, G. A. 2016. A survey of FLS2 genes from multiple citrus species identifies candidates for enhancing disease resistance to Xanthomonas citri ssp. citri. Hortic. Res. 3:16022.

Simon, R., Priefer, U., and Pühler, A. 1983. A broad host range mobilization system for in vivo genetic engineering: Transposon mutagenesis in gram negative bacteria. Nat. Biotechnol. 1:784-791.

Sun, W., Dunning, F. M., Pfund, C., Weingarten, R., and Bent, A. F. 2006. Within-species flagellin polymorphism in Xanthomonas campestris pv campestris and its impact on elicitation of Arabidopsis FLAGELLIN SENSING2-dependent defenses. Plant Cell 18:764-779.

Sun, Y., Li, L., Macho, A. P., Han, Z., Hu, Z., Zipfel, C., Zhou, J. M., and Chai, J. 2013. Structural basis for flg22-induced activation of the Arabidopsis FLS2-BAK1 immune complex. Science 342:624-628.

Takai, R., Isogai, A., Takayama, S., and Che, F. S. 2008. Analysis of flagellin perception mediated by flg22 receptor OsFLS2 in rice. Mol. Plant-Microbe Interact. 21:1635-1642.

Tans-Kersten, J., Brown, D., and Allen, C. 2004. Swimming motility, a virulence trait of Ralstonia solanacearum, is regulated by FlhDC and the plant host environment. Mol. Plant-Microbe Interact. 17:686-695.

Trdá, L., Fernandez, O., Boutrot, F., Héloir, M. C., Kelloniemi, J., Daire, X., Adrian, M., Clément, C., Zipfel, C., Dorey, S., and Poinssot, B. 2014. The grapevine flagellin receptor VvFLS2 differentially recognizes flagellin-derived epitopes from the endophytic growth-promoting bacterium Burkholderia phytofirmans and plant pathogenic bacteria. New Phytol. 201:1371-1384.

Trinquier, A., Durand, S., Braun, F., and Condon, C. 2020. Regulation of RNA processing and degradation in bacteria. Biochim. Biophys. Acta. Gene Regul. Mech. 1863:194505.

Veluchamy, S., Hind, S. R., Dunham, D. M., Martin, G. B., and Panthee, D. R. 2014. Natural variation for responsiveness to flg22, flgII-28, and csp22 and Pseudomonas syringae pv. tomato in heirloom tomatoes. PLoS One 9:e106119.

Vinatzer, B. A., Monteil, C. L., and Clarke, C. R. 2014. Harnessing population genomics to understand how bacterial pathogens emerge, adapt to crop hosts, and disseminate. Annu. Rev. Phytopathol. 52: 19-43.

Wang, S., Sun, Z., Wang, H., Liu, L., Lu, F., Yang, J., Zhang, M., Zhang, S., Guo, Z., Bent, A. F., and Sun, W. 2015. Rice OsFLS2-mediated perception of bacterial flagellins is evaded by Xanthomonas oryzae pvs. oryzae and oryzicola. Mol. Plant 8:1024-1037.

Wolf, D. M., Fontaine-Bodin, L., Bischofs, I., Price, G., Keasling, J., and Arkin, A. P. 2008. Memory in microbes: Quantifying historydependent behavior in a bacterium. PLoS One 3:e1700.

Yan, X., Zhang, Q., Zou, J., He, C., and Tao, J. 2019. Selection of optimized reference genes for qRT-PCR normalization in Xanthomonas campestris pv. campestris cultured in different media. Curr. Microbiol. 76:613-619.

Yaryura, P. M., Conforte, V. P., Malamud, F., Roeschlin, R., de Pino, V., Castagnaro, A. P., McCarthy, Y., Dow, J. M., Marano, M. R., and Vojnov, A. A. 2015. XbmR, a new transcription factor involved in the regulation of chemotaxis, biofilm formation and virulence in Xanthomonas citri subsp. citri. Environ. Microbiol. 17:4164-4176.

Yu, X., Lund, S. P., Scott, R. A., Greenwald, J. W., Records, A. H., Nettleton, D., Lindow, S. E., Gross, D. C., and Beattie, G. A. 2013. Transcriptional responses of Pseudomonas syringae to growth in epiphytic versus apoplastic leaf sites. Proc. Natl. Acad. Sci. U.S.A. 110: E425-E434.

Zipfel, C., Robatzek, S., Navarro, L., Oakeley, E. J., Jones, J. D., Felix, G., and Boller, T. 2004. Bacterial disease resistance in Arabidopsis through flagellin perception. Nature 428:764-767. 